Earth and Environmental Science Transactions of the Royal Society of Edinburgh

http://journals.cambridge.org/TRE

Additional services for Earth and Environmental Science Transactions of the Royal Society of Edinburgh:

Email alerts: $\underline{\text { Click here }}$

Subscriptions: $\underline{\text { Click here }}$

Commercial reprints: $\underline{\text { Click here }}$

Terms of use : $\underline{\text { Click here }}$

\title{
Endemic thelodonts (Vertebrata: Thelodonti) from the Lower Silurian of central Asia and southern Siberia
}

\section{Živilè Žigaitè}

Earth and Environmental Science Transactions of the Royal Society of Edinburgh / FirstView Article / November 2013, pp 1 - 21 DOI: 10.1017/S1755691013000467, Published online: 29 November 2013

Link to this article: http://journals.cambridge.org/abstract_S1755691013000467

How to cite this article:

Živilè Žigaitè Endemic thelodonts (Vertebrata: Thelodonti) from the Lower Silurian of central Asia and southern Siberia. Earth and Environmental Science Transactions of the Royal Society of Edinburgh, Available on CJO 2013 doi:10.1017/ S1755691013000467

Request Permissions : $\underline{\text { Click here }}$ 


\title{
Endemic thelodonts (Vertebrata: Thelodonti) from the Lower Silurian of central Asia and southern Siberia
}

\author{
Živilè Žigaité $\dot{e}^{1,2}$
}

${ }^{1}$ Evolution and Development, Department of Organismal Biology, Uppsala University, Norbyvägen 18A, SE-75236
Uppsala, Sweden.

${ }^{2}$ CNRS FRE 3298 Géosystèmes, University of Lille - 1, Palaeozoic Palaeontology and Palaeogeography, F-59655 Villeneuve d'Ascq Cedex, France.

Email: Zivile.Zigaite@gmail.com

\begin{abstract}
New fossil vertebrate microremains from the Lower Silurian of NW Mongolia, Tuva and S Siberia have been discovered, and previous collections of thelodonts (Vertebrata: Thelodonti) from this region re-studied, figured and described, following recent advances in morphology and systematics of thelodont scales. As a result, six thelodont species are described here and attributed to two families and three genera. An emended diagnosis is given for each species. Morpohological scale varieties of each species are revised, and the squamation types are introduced to the species descriptions, resulting in newly grouped morphological sets of scales. The previously monotypic genus Talimaalepis Žigaite, 2004, is proposed to contain two different species; therefore, two new combinations of morphological scale sets of two species are described for the first time. Both of them show transitional scale structure between the genera Loganellia (family Loganellidae) and Helenolepis (family Phlebolepididae). Two of the thelodont genera, Angaralepis and Talimaalepis, as well as all the six species, are endemic and not known anywhere else in the world. They are accompanied by a variety of other peculiar early vertebrates, such as mongolepids, two endemic genera of acanthodians, and putative galeaspids. This work enhances our knowledge of early Silurian vertebrate diversity, and provides evidence of regional palaeoenvironmental conditions and palaeogeographical relationships of the Siberia and Tuva terranes.
\end{abstract}

KEY WORDS: Angaralepis, early vertebrates, Loganellia, Mongolia, palaeobiogeography, Talimaalepis, Tuva

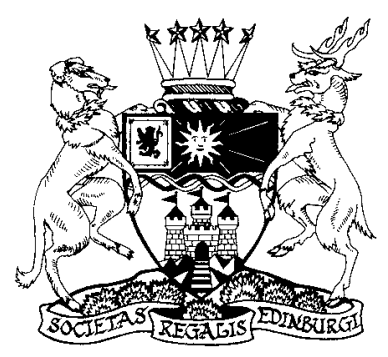

Thelodonts are among the most challenging of jawless Palaeozoic vertebrates to study, as they are most often preserved as disarticulated micromeric dermal scales, showing little or no external or internal body structure. Since the 19th Century, attempts to resolve the phylogenetic history of thelodonts have been hampered by a lack of full understanding of the range of intraspecific variation in thelodont scales. The earliest works of Gross $(1967,1968)$ demonstrated that the external structure of scales was not particularly informative without knowledge of scale histology and development. In addition, only a few taxa are available as articulated fossil specimens, and yet in the case of disarticulated microremains of thelodont dermoskeleton (scales) alone, it is often difficult to ascertain their intraspecific variation and higher taxonomical affinities.

Microremains of thelodont dermal skeletons are now known from the Early and Middle Palaeozoic (Upper Ordovician to Upper Devonian) from all over the world. This paper concentrates on the present-day territory of central Asia - NW Mongolia and the Tuva Republic - as well as central and southern parts of Eastern Siberia between the Yenisey and Lena rivers (Siberian platform), which is inferred to represent a united Siberian palaeocraton, an independent geological terrane that existed during the Palaeozoic (Cocks \& Torsvik 2007). In the Silurian, it comprised not only a large area of modern Russia (including Altai, Salair, Sayan, Siberia and Tomsk) and the northwestern part of Mongolia, but also extended into northwestern China (e.g. Afanassieva \& Janvier 1985; Sansom 2009). Siberia was the only large palaeoterrane in the Northern Hemisphere for much of the Palaeozoic (Cocks \& Torsvik 2007), and it was comparatively isolated at relatively high latitudes, which meant that the area was colonised throughout the Palaeozoic by marine benthic faunas and, later in the Palaeozoic, by both marine and terrestrial floras and faunas that are not found elsewhere. These biota were often sufficiently distinctive (e.g. Blieck \& Janvier 1993; Tesakov et al. 2003; Žigaitè et al. 2011; Wang et al. 2011) to form the basis of faunal palaeoprovinces at various times.

Vertebrate fossils were already reported from the Silurian rocks of this region more than 30 years ago. Materials from NW Mongolia were originally provided by L. Rosman, and more recently by I. Sodov; those from the Tuva Republic and the Siberian part of Russia were collected during the years 1968-1987, by V. Karatajūtè-Talimaa (Vilnius, Lithuania), T. Moskalenko, L. Aksenova, N. Kulkov and L. Ratanov (Novosibirsk, Russia). The first descriptions of thelodont microremains from the Lower Silurian of Siberia and Tuva were made by V. Karatajūtè-Talimaa, and were published as part of a monograph in Russian (Karatajūtè-Talimaa 1978); later Blieck \& Janvier (1993) and Turner (1999) summarised the findings in English. Since that time, no comprehensive description of thelodonts from the region has been made (Karatajūtè-Talimaa 1997; Karatajūtè-Talimaa \& Ratanov 2002; Žigaite \& Blieck, 2006; Žigaite et al. 2011), although further collecting of vertebrates at the localities continued.

The main purpose of this study is to describe new thelodont material from the later field collections and compare them with that previously collected. Here I present new descriptions of additional material, revealed from previously unprocessed 
rock samples, along with a revised analysis of all the thelodont fossils available from these collections. Thin sections, published as drawings by Karatajūtė-Talimaa (1978), have been re-examined and photographed. New SEM pictures of associated and new morphological scale sets of thelodont species, as well as new thin sections and high-resolution histological images, have been made. The thelodont descriptions in this work reflect the most recent nomenclature and terminology of thelodont microremain morphology and systematics (Karatajūtè-Talimaa \& Märss 2004; Märss et al. 2007), and of thelodont squamation types, following Märss (1986), (see also Turner 2000; Zigaite \& Goujet 2012). The former categories of head, transitional and body scales, have been adapted to the current division of thelodont scales by Märss (1986) as follows : rostral (= head); cephalo-pectoral (= transitional and 'transitional' body scales), corresponding to body scales contiguous with the head scales and terminating near the pectoral fins; postpectoral and precaudal (= most of the body scales); and pinnal (= special) scales, the latter including thelodont scales reported as belonging to the edges of the fins.

\section{Geological setting}

\subsection{NW Mongolia}

Vertebrate microremains discussed in this work come from the Lower Silurian section in North-West Mongolia, located on the south-east slope of Mount Chargat, $80 \mathrm{~km}$ north of Lake Khar-Us. The samples analysed originate from the Lake Basin outcrop at the Chargat locality, in the Khutsyn-Bulag Member of the Lower Wenlock Chargat Formation (Rozman 1986; Minjin et al. 2001). The section comprises a molasse-type sequence, characterised by brown and red-coloured conglomerates, clayey limestone breccias, and concretionary sandstones with limestone interlayers containing rich faunas (Minjin et al. 2001). The limestone inliers represent marginal shallow-water sedimentary facies rich in fauna, including the numerous vertebrate microremains first reported by Karatajūtè-Talimaa et al. (1990).

\subsection{Tuva}

Vertebrate samples including the thelodont scales discussed here, were collected from the Lower Silurian of the KyzylTchiraa, Elegest and Kadvoi sequences, which range from the upper Llandovery to the Wenlock. Dating of the Lower Silurian sequences has mainly been established on conodont biostratigraphy (Vladimirskaya et al. 1986). The lower and middle Llandovery are represented by the Alash Formation (Rhudanian-Aeronian), comprising fine-grained to coarse sandstones with limestone intercalations rich in fauna. The upper Llandovery is represented by two formations, the Kyzyl-Tchiraa Formation (lower Telychian) and the Angatchi Formation (upper Telychian); the latter has been described as lower Sheinwoodian in age (Karatajūtè-Talimaa \& Ratanov 2002). The formations are composed of fine-grained laminated sandstones with limestone intercalations. The lower Wenlock corresponds to the Akchalym Formation (lower-middle Sheinwoodian), composed of siltstones with clayey interbeds, but barren of vertebrate fauna. The upper Wenlock sediments correspond to the Dashtygoi Formation (upper Sheinwoodian-middle Ludlow), composed of condensed limestones with thin siltstone intercalations (Vladimirskaya et al. 1986; Karatajūtè-Talimaa \& Ratanov 2002).

\subsection{East Siberia}

The Silurian of East Siberia is divided into "subregions" and "districts" on the basis of persistent lithofacies (Tesakov et al.
2003). Five subregions are recognised: the North Tarym, North Preyenisey, Pretunguska, Nyuya-Beresovo and Irkutsk subregions. Lower Silurian vertebrates have been recorded in all of them. Virtually the entire Silurian of the southeastern part of the East Siberia is represented by gypsiferous argillaceous dolostone. Unrestricted marine conditions associated with the deposition of carbonates with corals and stromatoporoids occurred only episodically (Wenlock of the Nyuya-Beresovo district). The vertebrate-yielding Silurian sections in the southernmost part of the palaeobasin (Balturino district) are composed mainly of variegated sandstones and siltstones (Tesakov et al. 2003).

Vertebrate microremains are most abundant in the shallowshelf facies such as the brachiopod limestone in the Preyenisey subregion, the open shallow-shelf facies with diverse benthic fauna in the Pretunguska subregion, the lagoonal dolomitic marl with abundant fish and eurypterid fossils in the NyuyaBeresovo subregion, and the shallow-water, gypsum-bearing, dolomitic marl and sandstone from two lithostratigraphic districts of the Irkutsk subregion (Tesakov et al. 2003). The southernmost Balturino district (Irkutsk subregion) is particularly rich in vertebrate-bearing Silurian sequences.

Thelodonts are most common in the southern and southeastern Nyuya-Beresovo, Ilim and Balturino districts, corresponding to the Nyuya-Beresovo and Itrkutsk subregions. The Nyuya-Beresovo stratigraphic district is located near the middle reaches of the Lena River and its Nyuya, Dzherba and Biryuk River tributaries. The thelodont discoveries are restricted to the Llandovery series and two formations: the Melichan Formation, lower Llandovery (Rhudanian-lower middle Aeronian), and the Utakan Formation (upper middle Aeronian-Telychian). The Ilim stratigraphic district, comprising the drainage basins of the middle Angara River and the Ilim River, yielded vertebrates from only the Rassokha Formation (Rhudanian-Telychian). The Southern most Balturino stratigraphic district, named for Balturino village, lies in the Uda and Biryusa River drainage basins (Tesakov et al. 2003), with the Llandoverian series represented only by the Balturino Formation (Rhudanian-Telychian). The Wenlock series of the Balturino district comprises the Barmo Beds (see Tesakov et al. 2003 and Žigaite et al. 2011 for further details).

Thelodonts have also been found in the Turukhansk and Kochumdek districts. The Turukhansk stratigraphic district is located in the West Siberian platform, in the lower reaches of the Kureyka and Nizhnyaya Tunguska rivers. Thelodont microremains come from the upper Llandovery (uppermost middle Aeronian-Telychian) Omnutakh Formation. The Kochumdek district is located along the northern Yenisey Ridge, close to the Kochumdek River, a tributary of the Podkamennaya Tunguska River. The lower Llandovery of the Kochumdek district is represented by the Kochumdek Formation (Rhudanian-lower Aeronian), and the middle Llandovery by the Kulinna Formation (middle-upper Aeronian). The overlying Razvilka Formation (upper Llandovery, Telychian) is followed by the Usas Formation (Wenlock-uppermost Gorstian). All four formations yielded the thelodont scales discussed in this work; their biostratigraphic distribution was illustrated by Žigaite \& Blieck (2006). In addition to the thelodonts, the vertebrate fauna from these sections comprises abundant acanthodian, chondrichthyan, heterostracan and mongolepid microremains (Kratajūtè-Talimaa et al. 1990, Kratajūtè-Talimaa \& Predtechenskyj 1995; Žigaitè et al. 2011).

The geographical distribution of Lower Silurian thelodontbearing localities in East Siberia the Tuva Republic and northwest Mongolia, as well as the possible margins of the Early Silurian palaeobasin, are demonstrated in Figure 1. 


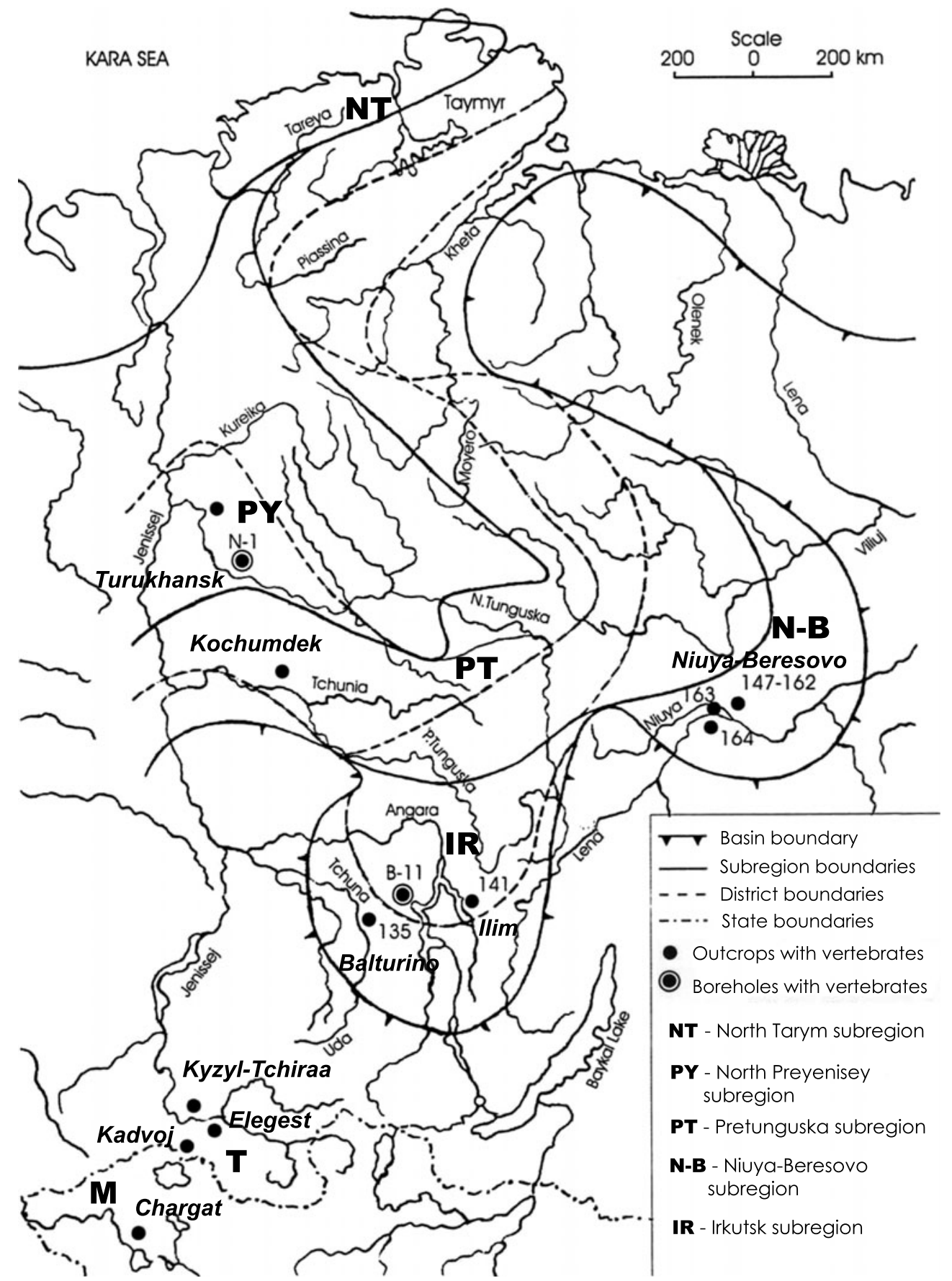

Figure 1 The geographical distribution of Lower Silurian thelodont-bearing localities in East Siberia, the Tuva Republic (T) and Northwest Mongolia (M).

\section{Materials and methods}

Samples of vertebrate microremains from the Lower Silurian of NW Mongolia, Tuva and East Siberia, ranging in age from Early Llandovery to Late Wenlock, were obtained from the collections of several expeditions.

The fossil material studied here includes disarticulated microremains of phosphatic early vertebrate exoskeletons, obtained by dissolving carbonate rock samples from northwestern Mongolia. Complementary fossil studies comprise already dissolved phosphatic microremains from central Tuva and East Siberia (V. Karatajūte-Talimaa collection). The majority of the vertebrate microremains originates from outcrop samples, with the exception of a few borehole samples from the middle part of the Siberian platform.
The collections in Mongolia were made by former Soviet Union geological expeditions (as noted above) by Rosman (sample P 16/3) and Sodov (samples 1009/1-4); the latter material was received as whole rock samples, and processed and initially examined recently, by the author (Žigaite 2004). The collections in central Tuva were made by Karatajūtė-Talimaa, Vladimirskaya, Predtechenskyj, Tesakov, Moskalenko, Aksenova, Kulkov, Ratanov and D. V. Obruchev in 1968 and 1971, as noted above, and during subsequent expeditions in East Siberia in 1982 and 1984.

The unprocessed conglomerate limestone samples were dissolved using 5\% acetic acid solution, and the resultant residues containing phosphatic vertebrate microremains were picked and sorted. Nearly 1000 isolated scales were studied on an FEI Quanta 200 SEM, with X-ray microanalysis and digital imaging. 
For histological study, about 150 scales were thin-sectioned manually, using a matrix of Canada balsam and, in about 100 of them, the histology was examined under high-resolution Zeiss Axioplan and Zeiss Axioscop light optical microscopes. In addition, the internal structure of approximately 100 microremains of favourable preservation (thin constitution and light colour) were studied under the optical microscope without thin sectioning, submerged in anise oil. These analyses were made in the CNRS research unit UMR 8157 "Géosystèmes", at the University of Lille 1 (France).

The size of the thelodont scales, given within the descriptions of each species, is subdivided as follows: very small, $0.1-0.5 \mathrm{~mm}$; small, $0.5-1.0 \mathrm{~mm}$; medium, $1-2 \mathrm{~mm}$; and large, 2-3.7 mm (after, e.g., Märss et al. 2006). The morphological sets of scales of each species have been arranged in clusters of morphological varieties, organised with respect to scale shape. These varieties in scale shape or sculpture presumably reflect inferred skeletal functions of the scales, and different parts of the body and squamation patterns, respectively (e.g., Gross 1967; Karatajūtè-Talimaa 1978; Märss 1986; Turner 2000). The squamation varieties of the thelodont exoskeleton comprise five main types and five morphological varieties of scales, respectively: rostral, cephalo-pectoral, postpectoral, precaudal and pinnal scales (Märss 1986, as mentioned above). This classification serves as a basis for establishing the intra-specific variability of exoskeleton elements (dermal scales), and thus the recognition of palaeospecies (Märss \& Ritchie 1998; Karatajūtè-Talimaa 1998; Märss et al. 2006, 2007).

All the specimens described in this work are deposited in the Department of Geology and Mineralogy, Vilnius University (Lithuania) and the Department of Evolution and Development, Uppsala University (Sweden), as nominal collections of V. Karatajūtè-Talimaa. The original series number LGI (after the previous host, Institute of Geology and Geography of Lithuania) has been kept. The collection series numbers are as follows: LGI M-1 (corresponding to northeastern Mongolia) LGI-T (corresponding to the collections from Tuva), and LGI-10 (corresponding to the collections from central and S Siberia).

\section{Systematic palaeontology}

Class Thelodonti Kiaer, 1932

Order Sandiviiformes Karatajūtė-Talimaa \& Märss, 2004

Family Angaralepididae Märss \& Karatajūtè-Talimaa, 2002

Type genus. Angaralepis Karatajūtè-Talimaa, 1997.

Type species. Angaralepis moskalenkoae (Karatajūtè-Talimaa, 1978).

\section{Angaralepis moskalenkoae (Karatajūtè-Talimaa, 1978)}

(Figs 2, 8A)

1967 Logania cf. cruciformis Gross, p. 36-37, pl. 4, figs 1-9, $12 \mathrm{~A}-\mathrm{J}$.

1978 Logania cf. cruciformis Gross, 1967; in Karatajūtė-Talimaa, p.86, pl. XX, 1, 13, 14; fig. 18, 4-6.

1978 Logania moskalenkoae Karatajūtè-Talimaa, p.86, Pl. XX, 15-19; fig. 18, 7-9.

1995 Loganellia? moskalenkoae; (Karatajūtè-Talimaa), in Karatajūtė-Talimaa \& Predtechenskyj, p. 43, figs 4-5.

1997 Angaralepis moskalenkoae (Karatajūtè-Talimaa); Karatajūtė-Talimaa, p. 9, 10; fig. 5, 6 .

2007 “Logania?” cf. cruciformis (Karatajūtè-Talimaa, 1978) Märss et al., p. 61.
Holotype. LGI 10-148, body scale, tab. XX, fig. 17, Karatajūtè-Talimaa 1978.

Type locality and horizon. Nizhniaya Tchunku river outcrop, Kochumdek district, Pritunguska subregion, East Siberia, Russia; Lower Silurian, Upper Llandovery, Razvilka Formation, outcrop Nr. 2 (Moskalenko 1968).

Material. Several thousand well-preserved scales; collection series number LGI 10; of which LGI 10-301 to LGI 10-320 have been pictured under the SEM; and LGI 10-174, studied and pictured as thin sections.

Geographical and stratigraphical range. Lower Silurian, Lower and Upper Llandovery, Moyerocanian and Agidyan Regional Stages, Raasokha Formation; Ilim district, Irkutsk subregion, East Siberia, Russia. Lower Silurian, Middle and Upper Llandovery, Khaastyrian and Agidyan Regional Stages, Utakan Formation; Niuya-Beresovo district, Niuya-Beresovo subregion, East Siberia, Russia. Lower Silurian, Upper Llandovery, Agidyan Regional Stage, Razvilka Formation; Kochumdek district, Pretunguska subregion, East Siberia, Russia.

Emended diagnosis (modified after Karatajūtè-Talimaa 1997). Scales are small (0.2-0.4 mm long), wide and high in comparison to their length. Crown is strongly serrated, with sharp central crest and at least two, most often three, pairs of uniformly sharp lateral ribs, all converging towards a sharp, pointed, arrow-like posterior end. Sharp notches of the ribs characterise the anterior rim of the crown, while the posterior part has one or three pointed end-notches. Neck is high, usually with vertical ridgelets on its posterolateral walls. Base is low, rhomboid and smaller than the crown, except in the older rostral scales, where pulp depression is wide and shallow. Any scales with overgrown pulp opening or very high or thick base have not been observed. Dentine is composed of thin tubules, which are narrow, do not branch and extend regularly; pulp cavity is not developed.

Remarks. The first collection of the scales from a locality on the Lower Tchunku river (Kochumdek district, Pritunguska subregion, W East Siberia, Russia) was made by T. A. Moskalenko in 1968, and this was the basis on which Logania moskalenkoae Karatajūtè-Talimaa 1978 was described. However, that series contained only a few head and body scales (Karatajūtè-Talimaa 1978, table XX, figs 13-19). Later, more numerous material was found in Middle Llandovery rocks (Niuya-Beresovo district, Niuya-Beresovo subregion, East Siberia, Russia), yielding well-preserved transitional and body scales, and the species was determined as Loganellia? moskalenkoae by Karatajūtè-Talimaa \& Predtechenskyj (1995). This range allowed Karatajūte-Talimaa to complement the morphological series, as well as histological study, and for the species to be ascribed to a new genus, Angaralepis Karatajūtè-Talimaa (1997), a new family, Angaralepididae Märss \& Karatajūtė-Talimaa (2002), and a new order, Sandiviiformes Karatajūtè-Talimaa \& Märss (2004) (Märss et al. 2007).

Further material has been revealed from the Upper Llandovery of the Ilim district, Ilim subregion, and the Niuya-Beresovo district, Niuya-Beresovo subregion (East Siberia, Russia), as well as from the Lower Llandovery (Ilim district, Ilim subregion, East Siberia, Russia).

In addition, I refer to A. moskalenkoae a set of cross-shaped scales, originally attributed to $L$. sp. cf. $L$. cruciformis by Karatajūtè-Talimaa (1978, p. 96, pl. XX: 1, 13, 14; fig. 18: 4-6). The interpretation of these scales as the head scale morphological type of L. cuneata was suggested at that time, and figured with their first description (Karatajūte-Talimaa, 1978), together with the possible attribution of these scales to L. moskalenkoae (Karatajūtè-Talimaa 1978, p. 98). Recently, Märss et al. (2007, 

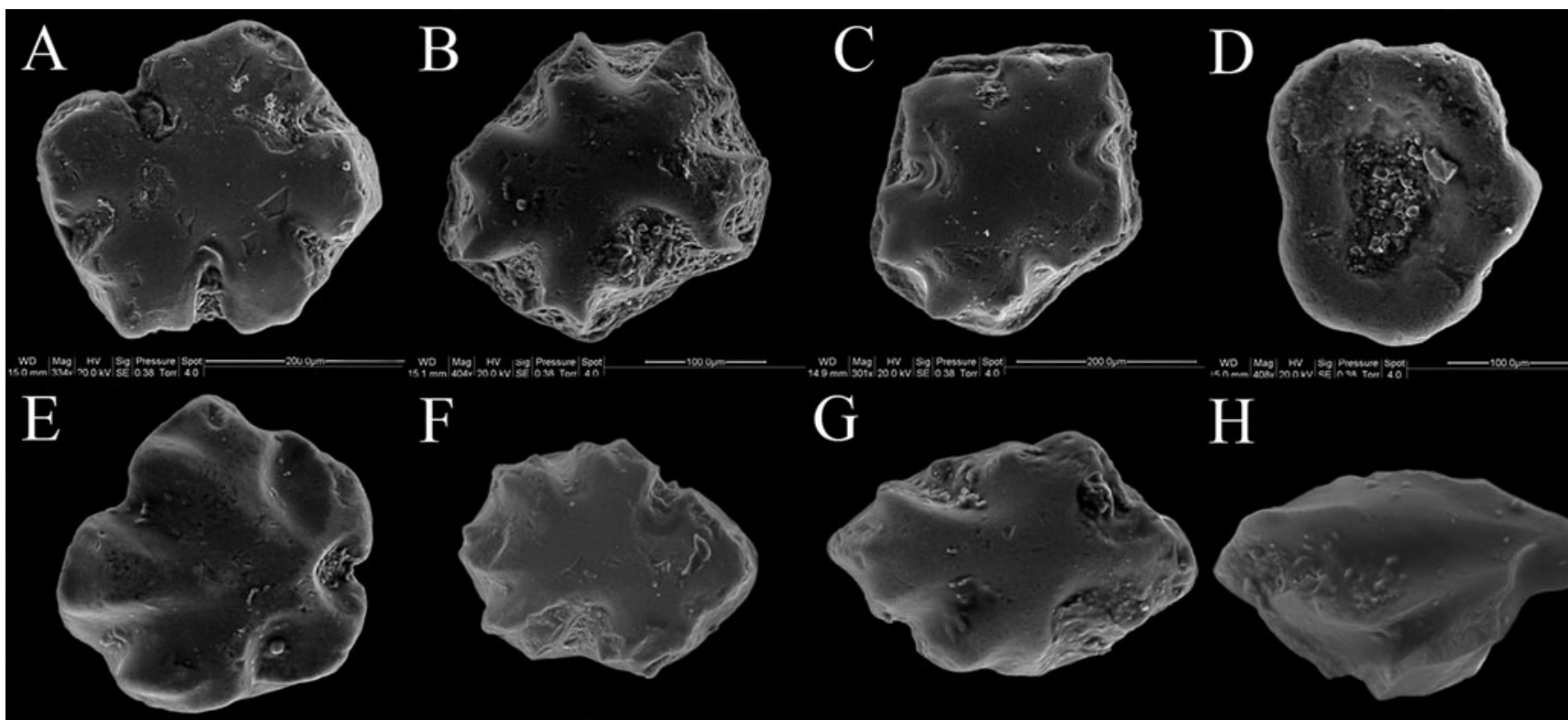

F
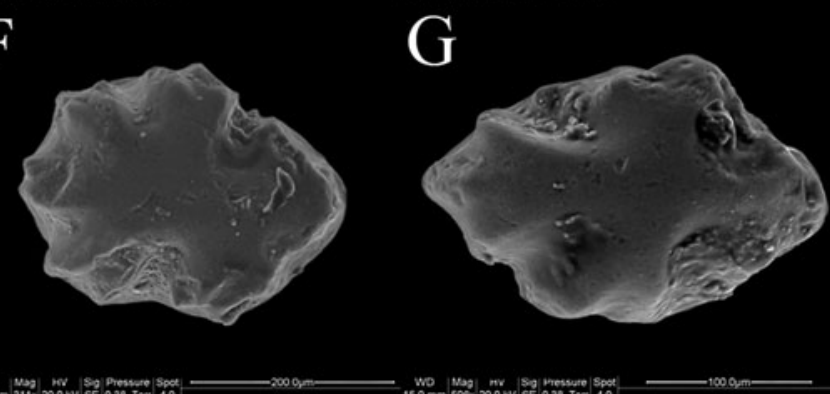

$\mathrm{H}$
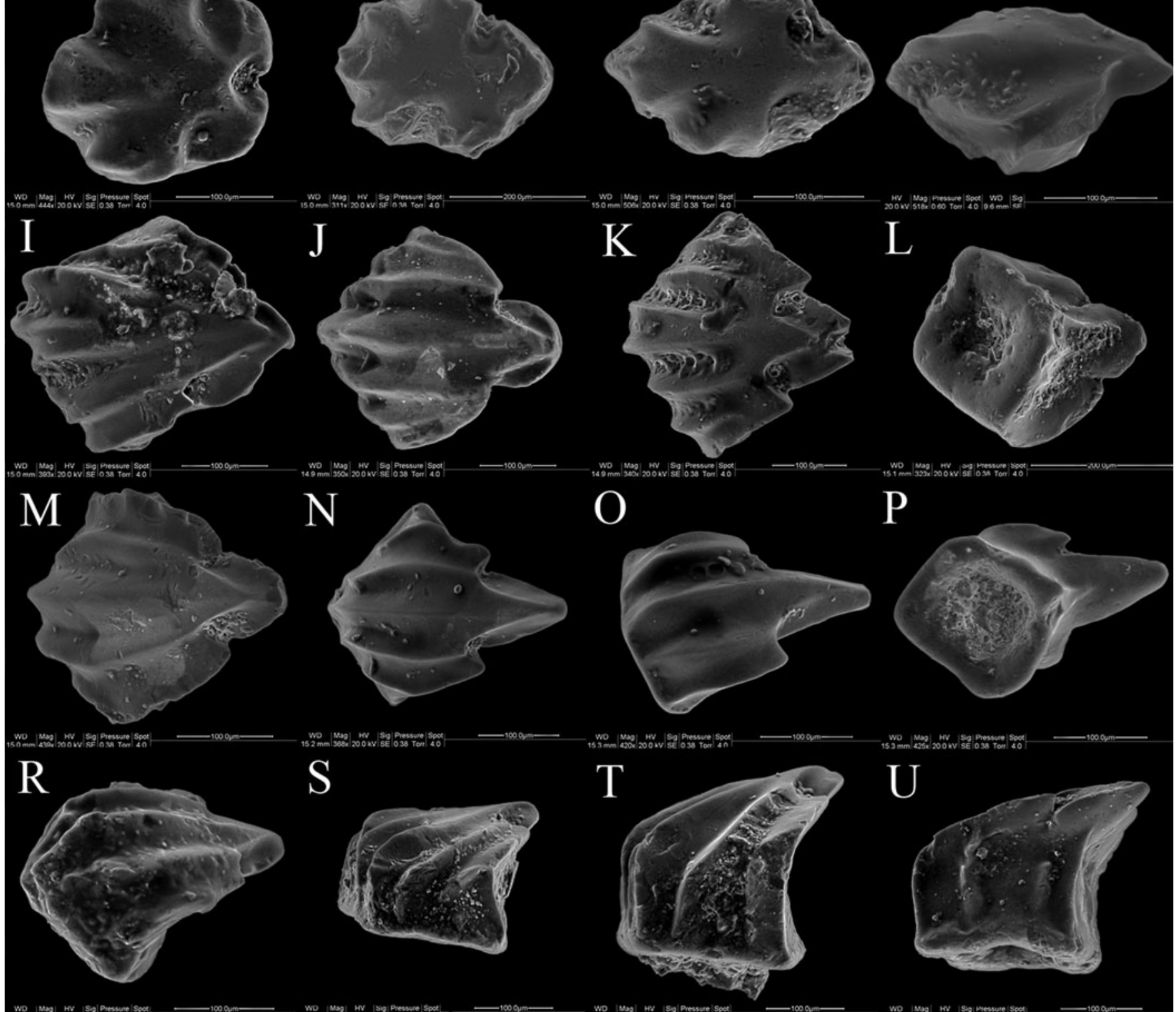

Figure 2 Angaralepis moskalenkoae (Karatajūtè-Talimaa 1978). (A-D) Rostral scales: (A)10-301; (B) 10-303; (C) 10-302; (D)10-304, basal view. (E-H) Cephalo-pectoral scales: (E) 10-305; (F) 10-306; (G) 10-307; (H) 10-308. (I-P) Postpectoral and precaudal scales: (I) 10-309; (J) 10-310; (K) 10-311; (L) 10-312, basal view; (M) 10-313; (N) 10-314; (O) 10-315; (P) 10-316, basal view. (R-U) Pinnal scales: (R) 10-317; (S) 10-318; (T) 10-319; (U) 10-320. Lower Silurian, Lower and Upper Llandovery, Moyerocanian and Agidyan Regional Stages, Raasokha Formation, Ilim district, Irkutsk subregion, East Siberia, Russia.

p. 61) have interpreted "Logania?" cf. cruciformis (KaratajūtèTalimaa 1978) as the head scales of some species of Loganellia. In this study, additional new material of A. moskalenkoae has been revealed, and scale histology has been examined, all indicating that $L$. sp. cf. L. cruciformis scales should be interpreted as the rostral (head) scales of A. moskalenkoae.
Any scales that might correspond to the leading edges of fins were not distinguished morphologically during the first description by Karatajūtè-Talimaa in 1978, although a histological thin section on one of the scales of this type was published (Karatajūtè-Talimma 1978; fig. 18: 7). 
Description. Morphology. Rostral scales are low, round, slightly oval or cross-shaped. The crown is low, with sharply and unevenly notched edges, forming characteristic crossshaped wings of the crown (Fig. 2A-D). The number of the notches usually varies from four to six, leaving a corresponding number of more or less sharpened cross-shaped crown ridges. The surface of the crown is smooth, flat or slightly bulging. The neck is reduced, and the base is very low, thin and sometimes almost invisible in the earliest stages of scale development. In the last case, rostral scales possess a very fine general morphology. In older scales, the base may become wider than the crown, which is the only case of a wider base, considering the whole morphological set of the species. The low cross-shaped scales of $L$. sp. cf. $L$. cruciformis (KaratajūteTalimaa 1978, p. 96, pl. XX: 1, 13, 14; fig. 18: 4-6), are attributed to the rostral scales of $A$. moskalenkoae herein.

Cephalo-pectoral scales correspond to the transitional scales, as determined by Karatajūtè-Talimaa (1978). They are oval, sharply wedged and still slightly cross-shaped, like the rostral scales (Fig. 2E-H). This type of A. moskalenkoae scale is the least abundant in comparison to other morphological types.

Postpectoral and precaudal scales are rhomboidal and slightly laterally expanded, with a typical serrated sculpture of the crown. The crown is high, wider than the base, with a sharp central crest and most often three pairs (Fig. 2I-K), or at least two pairs (Fig. 2L-P), of uniformly sharp lateral ribs of similar height, all converging towards a sharp, pointed posterior end. The crown can be divided into its high anterior part, covered with longitudinal ribs, and a narrower posterior part, which is usually anchor-shaped and separated from the anterior part by lateral cavities. The anterior rim of the crown is sharply notched, and the posterior part is arrow-like, with one (Fig. $2 \mathrm{O}$ ) or three (Fig. 2K) pointed end-notches. Sometimes the crown can be double-notched in its posterior part, so that the most lateral pair of ribs forms a lower plane with an anchorshaped end, and the central rib forms a arrow-shaped pointed end above it (Fig. 2M). The inner surface of the crown is smooth, only traces of lateral cavities can be distinguished. The posterior end of the crown is uplifted, at an angle of about $25-30^{\circ}$ in comparison to the base plane. The neck is high, often possessing vertical ridgelets on its posterolateral walls. The neck can also be divided into anterior and posterior parts, separated by very sharp ridges, descending from the last pair of the lateral ridges of the crown. The base is considerably narrower than the crown; it is low and has a shape of a wide rhomb, usually with a wide and shallow pulp depression. The pulp opening is never overgrown, even in mature scales. Scales with a high thick base have not been observed.

Pinnal scales are sharp and hook-shaped, very high, with distinct very sharp lateral ribs, continuously extending from the neck through to the crown, and converging to a pointed posterior end of the crown (Fig. 2R-U). Central and lateral ridges are rather uniform in width and shape, except that the central ridge is the longest one. The anterior and posterior parts can not be distinguished on the crown, unlike in the postpectoral and precaudal scales, but the pointed posterior end of the crown is considerably uplifted in comparison to its anterior rim, at about a $40^{\circ}$ angle in comparison to the base plane. The inner surface of the crown is not smooth, with the same sharp ridges as the outer surface. The neck is serrated, with vertical ridges along all of its walls, indistinctly continuous with the crown. The base is extremely low and slightly rhomboid; the pulp depression is very wide.

Histology. The internal structure of the A. moskalenkoae scales represents a regular thin tubule dentine: the dentine tu- bules are narrow, comparatively long, do not branch and extend rather straight, especially in the posterior part of the crown. Only some tubules near the base are slightly wider and branching (Fig. 8A). The pulp canal is not developed. Dentine tubules open directly onto the pulp depression, or onto the surface of the base, sometimes even on the lower surface of the crown. Few Sharpey's fibres have been observed in the base (Fig. 8A). The base is very low and comparatively small, and therefore most of the scale is composed of the dentine tissue.

Comparison. A. moskalenkoae possesses quite a distinct morphology as compared to the other thelodont species of the region. The specific sharp wedge-shaped midline trough and high number of lateral ribs are not characteristic to the genera Loganellia and Talimaalepis. Angaralepis also has a very high neck, in contrast to the always low or strongly reduced neck of loganiid and talimaalepid scales. The internal structure of the Angaralepis scales shares some similarities with loganiid scales; for example, the absence of a pulp depression and thicker dentine tubules, and the thin tubule dentine has quite a regular tubule branching pattern, in contrast to the irregular one found in loganiids. However, due to the distinct morphology, A. moskalenkoae is attributed to the order Sandiviiformes, as opposed to Loganellia and Talimaalepis, which belong to the order Loganelliiformes.

Order Loganelliiformes Turner, 1991

Family Loganelliidae Märss, Wilson \& Thorsteinsson, 2002

Type genus. Loganellia Fredholm, 1990 - Turner 1991.

Type species. Loganellia scotica (Traquair, 1898).

Remarks: Recently, Märss et al. (2007, p. 49) attributed the family name Loganelliidae to Märss et al. (2002), see also Hairapetian et al. (2008). However, Karatajūte-Talimaa first introduced the family Loganiidae (Karatajūtè-Talimaa 1978, p. 66) and then later she created the subfamily name Loganelliinae (Karatajūte-Talimaa 1997, p. 14), following the emendation of the genus name (Logania = Loganellia, Fredholm, 1990, p. 69). By creating the subfamily name, Karatajūtè-Talimaa is the author of the coordinate family name Loganelliidae (International Commission on Zoological Nomenclature 1999, article 36.1). As a result, the accurate family name citation would be "Loganelliidae Karatajūtè-Talimaa, 1978 emend Karatajūtè-Talimaa, 1997 (see also Märss et al. 2006, p. 16). Eventually, the Loganelliidae Märss et al. 2002 is choosen because earlier treatment of the taxon by Karatajute-Talimaa (1997) had mistakes. On page 2 she used Loganiidae (Karatajūtè-Talimaa, 1978) with type genus as Loganellia (Turner 1991) indicated. Loganiidae was not valid, as the family name must be based on the generic name valid at that time (i.e. Loganellia). On page 14 she established a new subfamily Loganelliinae, which was once thought to be correct, but it had two genera included and the subfamily had no diagnosis. Also, the type genus was not explicitly indicated.

The genus name Loganellia, in replacement of both "Logania" Gross, 1967 and "Loganella" Turner \& Peel, 1986, used to be attributed to Turner (1991), see e.g., Karatajūtè-Talimaa \& Märss (2004, p. 18), Märss et al. (2006, p. 17). However, the name Loganellia was first published by Fredholm (1990, p. 69), who inadvertently cited the article of Turner, which was in press at that time (published as Turner 1991). Therefore, the correct name should be "Loganellia Fredholm, 1990" (see Märss et al. 2007, p. 49; Hairapetian et al. 2008).

Loganellia asiatica (Karatajūtè-Talimaa, 1978) Figs 3, 8C, D 


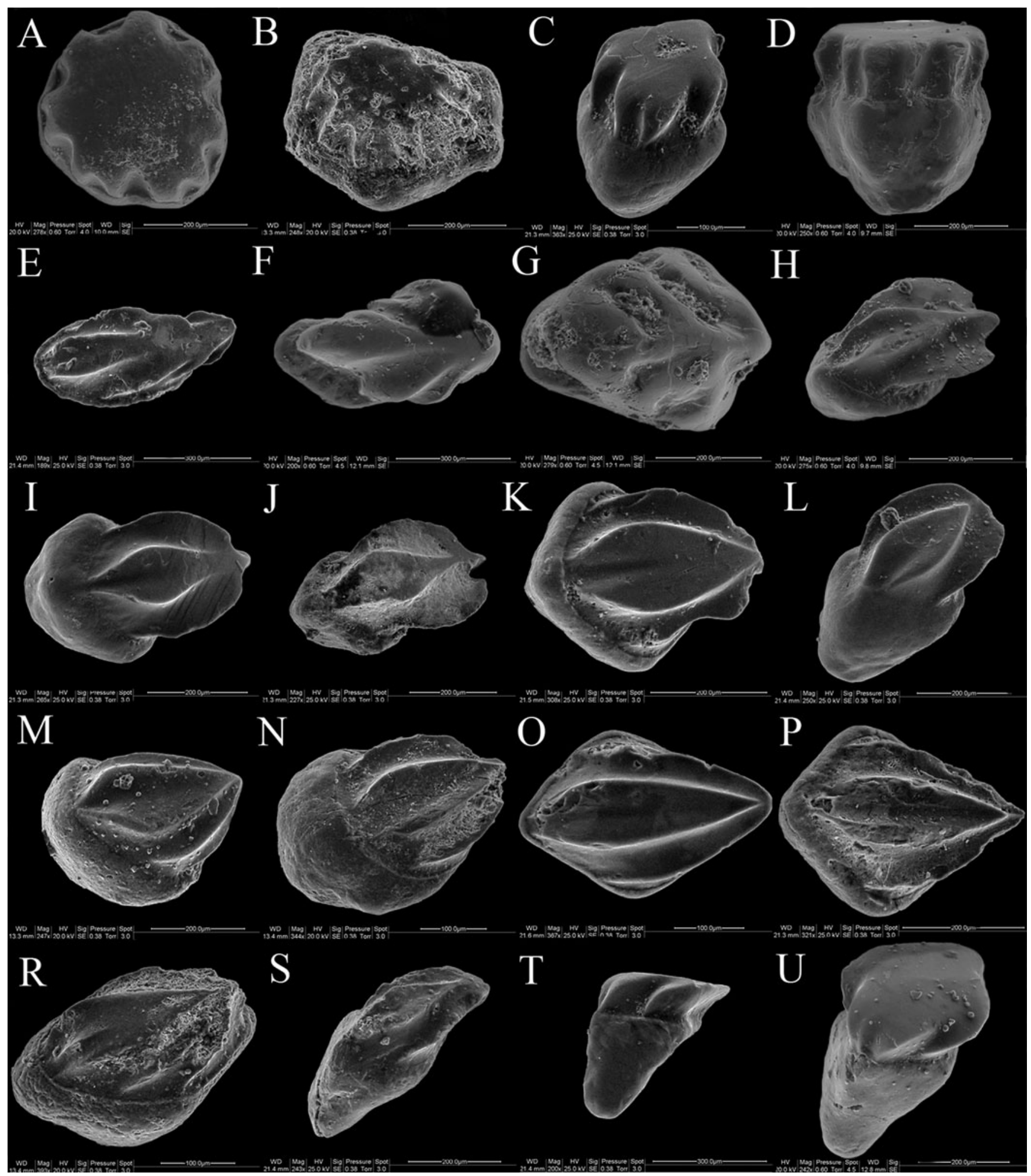

Figure 3 Loganellia asiatica (Karatajūtè-Talimaa 1978). (A-B) Rostral scales, type A: (A) T-550; (B) T-551. (C-D) Rostral scales, type B: (C) T-554; (D) T-555. (E-G) Cephalo-pectoral scales: (E) T-556; (F) T-557; (G) T-558. (H-S) Postpectoral and precaudal scales: (H) T-559; (I) T-560; (J) T-561; (K) T-562; (L) T-563; (M) T564; (N) T-565; (O) T-566; (P) T-567; (R) T-568; (S) T-569. (T-U) Pinnal scales: (T) T-570; (U) T-571. Lower Silurian, Upper Llandovery, Kyzyl-Tchiraa Formation, and Angatchi Regional Stages, Kyzyl-Tchiraa Formation, and Angatchi formations, Kyzyl-Tchiraa locality, central Tuva, Russia.

1978 Logania asiatica Karatajūtè-Talimaa, pp 73-76, Pl. XXI, 1-18; figs 6, 7A-B.

1995 Loganellia cf. asiatica; Karatajūtè-Talimaa \& Predtechenskyj, pp 45-49, figs 4, 5.

1997 Loganellia asiatica (Karatajūtè-Talimaa); KaratajūtèTalimaa, p. 2; p. 11, fig. 7B.
2004 Talimaalepis rimae Žigaite, p. 160, partim Pl. 1, fig, B, non $\mathrm{Pl}$. 1, figs $\mathrm{A}, \mathrm{C}-\mathrm{Z}$; p. 162, partim $\mathrm{Pl}$. 2, figs $\mathrm{A}, \mathrm{B}$, non $\mathrm{Pl}$. 2, figs $\mathrm{C}-\mathrm{O}$.

Holotype. LGI T-381, body scale, Karatajūtè-Talimaa 1978, Pl. XXI, fig. 8 . 
Type locality and horizon. Kyzyl-Tchiraa locality, central Tuva, Russia; Lower Silurian, Upper Llandovery, KyzylTchiraa Formation, Kyzyl-Tchiraa outcrop, sample Nr. 702 (Karatajūtè-Talimaa, 1978).

Material. More than 800 scales of different preservation; collection series number LGI T; of which LGI T-550 to LGI T-571 have been pictured by SEM; and LGI T-592 as thin section.

Geological and geographical range. Lower Silurian, Lower Llandovery, Moyerocanian Regional Stage, Melichan Formation; Niuya-Beresovo district, Niuya-Beresovo subregion, East Siberia, Russia. Lower Silurian, Lower, Middle and Upper Llandovery, Moyerocanian, Khaastyrian and Agidyan Regional Stages, Raasokha Formation; Ilim district, Irkutsk subregion, East Siberia, Russia. Lower Silurian, Lower, Middle and Upper Llandovery, Moyerocanian, Khaastyrian and Agidyan Regional Stages, Balturino Formation; Balturino district, Irkutsk subregion, East Siberia, Russia. Lower Silurian, Upper Llandovery, Kyzyl-Tchiraa Formation and Angatchi Regional Stages, Kyzyl-Tchiraa Formation and Angatchi formations; Kyzyl-Tchiraa locality, central Tuva, Russia. Lower Silurian, Wenlock, Salhit Regional Stage, Chargat Formation; Lake Basin outcrop Nr. 20, Chargat locality, Lake Khar-Us, northwest Mongolia (sample: P 16/3). Lower Silurian, Wenlock, Salhit Regional Stage, Chargat Formation; Lake Basin outcrop Nr. 21, Chargat locality, Lake Khar-Us, north-west Mongolia, (samples: 1009/1, 1009/2, 1009/3, and 1009/4). Lower Silurian, Upper Wenlock, Dashtygoi Regional Stage, Dashtygoi Formation; Elegest and Kadvoi localities, central Tuva, Russia.

Emended diagnosis (complementary to Märss et al. 2007). Scales are small, broad, short and thick, rounded-rhomboidal in shape, and quite uniform in size (length $0.3-0.6 \mathrm{~mm}$ and width $0.24-0.37 \mathrm{~mm}$ ). The crown is characterised by a distinct rhomboid middle segment, depressing sharply towards a median line. Lateral segments of the crown are wide, lower than the median one, and joined posteriorly in the same level. There is only one pair of lateral segments, rarely two pairs (Fig. 3R). The groove between the crown and the base is low. The base is high, with a distinct anterior vertical thickening. The pulp depression is situated in the posterior part of the scale, behind the vertical thickening of the base, overgrown in older scales. Dentine tubules are thin and branch irregularly, getting slightly wider towards the base, pulp canal is absent.

Remarks. Some scales initially ascribed to L. asiatica by Karatajūtè-Talimaa (1978, p. 297, Pl. XXI, fig. 17a, b) as body scales, are now assigned to Talimaalepis rimae Žigaitè, 2004, as postpectoral scales, on the basis of crown morphology, considering the sharp rhomboid uplifted trough in the centre of the scale. $L$. cf. asiatica described by Karatajūtè-Talimaa \& Predtechenskyj (1995, pp 45-49, figs 4, 5) is now also attributed to L. asiatica, which, after these records, appears to be the most common as well as the most abundant Lower Silurian thelodont species in the region.

Description. Morphology. Rostral scales present two main types of scales: the first consists of round or oval scales, with a low and flat crown, and a rather low base (Fig. 3A, B); the second is represented by round scales with a pointed proximal part of the crown and a very high base (Fig. 3C, D). The surface of the crown in both types is flat and smooth, sometimes slightly curved. The crown is always notch-edged; the notches vary in length, from short to quite deep. The base is generally wider than the crown. The pulp cavity is rhomboid or wedgeshaped in the low rostral scales, and occupies the very central part of the base. In the rostral scales with a very high base, the pulp cavity is usually overgrown.

Cephalo-pectoral scales are elongated, oak-leaf-like, with a sharp and pointed posterior end of the crown. The crown mor- phology varies greatly, from broad and rhomboid with a significantly wider posterior part (Fig. 3E), to elongated and narrow (Fig. 3F, G). Ribs are wide and rounded, joining to form a wide, rounded and not very prominent central crest, which usually does not stretch along the whole length of the crown. It may start from the middle of the scale, or terminate before the posterior part of the crown. The half-scale length of the central crest is particularly characteristic of the narrow and very elongated type of cephalo-pectoral scales, where the next pair of lateral ribs usually fuses to continue the crest. The base of the cephalo-pectoral scales is usually not very high, wider than the crown, and thicker in its anterior part. The pulp depression is elongated and can be partially overgrown in older scales, or presented as a set of small openings.

Postpectoral and precaudal scales have a prominent roundedrhomboid overall shape; they are broad, short and thick. The crown is usually well-embedded in a rather massive and high base, and can be characterised by a distinct rhomboid middle segment sharply sagged towards a median line. The median segment can be divided into two parts lengthways: a short and rounded anterior part and a much longer and pointed posterior part (Fig. 3H-S). On the sides of the median segment, there is usually one pair (rarely two pairs) of lateral ones. They stretch along the median part, lie at an angle to the median segment, and fuse at the posterior end of the crown. Where a second pair of lateral segments is present, it is usually very short and indistinct, hiding beneath the always well expressed first pair of segments. The anterior part of the crown is always lower than the base, in contrast to its always rising posterior part (Fig. $3 \mathrm{H}-\mathrm{S}$ ). The crown is never much longer than the base posteriorwards, usually one third or lees of the total crown lengh. The inner side of the crown is smooth. The base is wider than the crown, and rather high, and has distinct anterior vertical thickening. The pulp depression is oval and elongated, situated behind the vertical thickening in the posterior part of the scale, and is often overgrown in older scales. It may also be overgrown, or partialy overgrown and presented as a linear set of small openings.

Pinnal scales have a characteristic steep-edged anterior part of the crown, and an extremely high base with an amplified anterior part. The crown still has a significantly uplifted and pointed posterior end, but the characteristic median segment is much less distinguished than that of the postpectoral and precaudal scales. Two pairs of lateral segments are always present and lie at a steeper angle to the median segment, thus can be described as lateral ridges. The base is still slightly wider than the crown, and extremely high, usually $2-3$ times the crown height, with a vertically elongated anterior part.

Histology. Irregularly branching thin dentine tubules represent the internal structure of the scales (Fig. 8C, D). The net of thin tubules is denser in the posterior part of the scale, along its median line. The pulp canal is not developed, and dentine tubules open directly into a pulp depression on the posterior surface of the base, slightly widening at their terminal ends. Dentine tubules tend to remain parallel in the anterior part of the scale, and start branching irregularly in the uplifted posterior part. Sharpey's fibres are numerous in the vertical thickening of the base, usually extending from the base surface, and eventually narrowing and bending at the end of the base.

Comparison. Scale morphology of $L$. asiatica is comparable to $L$. sibirica, and particularly to $L$. scotica, the type species of the genus, with which it shares the characteristic rhomboid median segment. However, histologically, L. asiatica is closer to $L$. sibirica and L. tuvaensis, sharing a similar pattern of irregularly branching thin dentine tubules, and the absence of a pulp canal. This common internal structure was previously noted by Turner (1991), as an "achanolepid" type thelodont 
histology, and most recently the three species were attributed to Sandivia-type histology by Märss \& Karatajūtė-Talimaa (2002), outside of Loganellia-type histology (see also Märss et al. 2007). Regarding the uplifted median segment of the crown, L. asiatica is also slightly morphologically similar to Talimaalepis kadvoiensis (Karatajūtè-Talimaa 1978) Žigaite 2004 comb. nov., although histological differences are considered fundamental: scales of Talimaalepis are composed of much thicker dentine tubules (Figs 8G, H, 9D, E), while all the loganelliids have very thin dentine tubules (Fig. 8B-F).

\section{Loganellia sibirica (Karatajūtè-Talimaa, 1978)}

(Figs 4, 8B)

1968 “Phlebolepis" sp., Moskalenko, fig. 2: 12, 13, 14.

1978 Logania sibirica Karatajūtė-Talimaa, pp 70-73, Pl. XX, 2-12; fig. 18, 10-13.

1991 Loganellia sibirica; Turner, p. 87.

1995 Loganellia ex. gr. scotica; Karatajūtè-Talimaa \& Predtechenskyj, pp 45-49, figs 4, 5.

1997 Loganellia sibirica (Karatajūtè-Talimaa); KaratajūtèTalimaa, p. 2; p. 11, fig. 7a.

1997 Loganellia ex. gr. scotica Karatajūtè-Talimaa, p. 12, fig. $8 \mathrm{a}, \mathrm{b}, \mathrm{f}$.

Holotype. LGI 10-147, body scale, Karatajūtè-Talimaa 1978, Pl. XX, fig. 12.

Type locality and horizon. Nizhniaya Tchunku river outcrop, Kochumdek district, Pritunguska subregion, W Siberia, Russia; Lower Silurian, Middle Llandovery, Kulinna Formation, outcrop Nr. 3 (Moskalenko 1968).

Material. More than 600 scales, some of poor preservation, sculpture elements being obscure; collection series number LGI 10; of which LGI 10-260 to LGI 10-284 have been pictured by SEM, and LGI-488 as thin sections.

Geological and geographical range. Lower Silurian, Lower Llandovery, Moyerocanian Regional Stage, Kochumdek Formation; Lower Tchunku River, Kochumdek district, Pretunguska subregion, East Siberia, Russia. Lower Silurian, Lower Llandovery, Moyerocanian Regional Stage, Melichan Formation; Niuya-Beresovo district, Niuya-Beresovo subregion, East Siberia, Russia. Lower Silurian, Lower Llandovery, Moyerocanian Regional Stage, lower Balturino Formation; Balturino district, Balturino subregion, East Siberia, Russia. Lower Siliurian, Middle Llandovery, Alash Regional Stage, Alash Formation; outcrop Kadvoi, central Tuva, Russia (sample Kadvoi 694). Lower Silurian, Middle Llandovery, Khaastyrian Regional Stage, Kulinna Formation; Lower Tchunku River, Kochumdek district, Pretunguska subregion, East Siberia, Russia. Lower Silurian, Middle and Upper Llandovery, Khaastyrian and Agidyan Regional Stages, Utakan Formation; Niuya-Beresovo district, Niuya-Beresovo subregion, East Siberia, Russia. Lower Silurian, Lower, Middle and Upper Llandovery, Moyerocanian, Khaastyrian and Agidyan Regional Stages, Raasokha Formation; Ilim district, Irkutsk subregion, East Siberia, Russia. Lower Silurian, Wenlock, Salhit Regional Stage, Chargat Formation; Lake Basin outcrop Nr. 20, Chargat locality, Lake Khar-Us, north-west Mongolia (sample P 16/3). Lower Siliurian, Upper Wenlock, Dashtygoi Regional Stage, Dashtygoi Formation; outcrop Kadvoi, central Tuva, Russia (Kadvoi 662-663). Lower Siliurian, Upper Wenlock, Dashtygoi Regional Stage, Dashtygoi Formation; outcrop Kadvoi, central Tuva, Russia (sample Kadvoi 664).

Emended diagnosis (complementary to Märss et al. 2007). Scales are small and elongated $(0.2-0.6 \mathrm{~mm}$ long; $0.1-0.2$ $\mathrm{mm}$ wide). The crown is narrow, comparatively high, has a deep median trough and a pointed posterior end. Two pairs of lateral ribs are present; the first pair, and often the second pair, are longer than the median trough. The base is vertical and cone-shaped, with a thicker anterior part and no anterior spur-like process. Dentine tubules are thin and branch irregularly; pulp canal is absent.

Remarks. Three scales of $L$. sibirica were sketched by T. A. Moskalenko (1968) as scales similar to the ones of genus Phlebolepis (Moskalenko 1968, figs 2, 12a, b, 13, 14). They were later described as Logania sibirica by Karatajūtè-Talimaa (1978), and then determined as Loganellia sibirica (Karatajūtè-Talimaa, 1978) by Turner (1991). Loganellia ex. gr. scotica (Karatajūtè-Talimaa \& Predtechenskyj, 1995, pp. 45-49, figs 4, 5) scales first described in the Lower Silurian of the Siberian platform, is now attributed to $L$. sibirica as well. Very few scales of $L$. sibirica have been recorded in the Wenlock of NW Mongolia, yet additional material has been revealed from the Lower Llandovery and Upper Wenlock samples of central Tuva, which refutes the previously stated species palaeobiogeographical restriction to the Lower Silurian of Mongolia and Siberian platform (see Žigaite \& Blieck 2006).

Description. Morphology. Rostral scales are small, round or oval, with a comparatively high base and a low notch-edged crown. The crown has a flat and smooth surface, steep edges, but not very deep notches (Fig. 4A-C). The base is slightly wider than the crown, its height depending on the stage of ontogenetic development of a scale (Fig. 4D). The pulp cavity is in the centre of the base; it is rather wide and shallow.

Cephalo-pectoral scales are elongated and relatively narrow. The crown is high, oak-leaf-like (Fig. 4E) or slightly cylindrical, with several pairs of descending lateral ribs (Fig. 4F-H). The central crest is well expressed, elevated, rises up posteriorly and often begins from the median pair of ribs, joining into a central rising in the posterior part of the scale (Fig. $4 \mathrm{~F}-\mathrm{H})$. All the ribs are more or less inclined, topping towards the posterior end of the crown, giving a shape of pointed triangle (Fig. 4F, G). The distal junctions of the lateral rib pairs often form a central crest on the posterior top of the crown. The base is usually smaller than the crown, higher or lower depending on the individual age of each scale. The crown slightly overhangs the base.

Postpectoral and precaudal scales range from very narrow and elongated to oval and finally gently rhomboid ones (Fig. 4I-U). The crown is less high and overhangs at least half of the base, in contrast to the cephalo-pectoral scales. The anterior part of the crown is usually wider (Fig. 4I-R) than it is in the case of the narrow and tiny precaudal scales (Fig. 4S-U). A shallow median trough between the central ribs extends along the crown top surface, narrowing and finally closing up at the posterior end of the crown. Lateral troughs and lateral ribs are situated below the median ones. A shallow groove separates the crown from the base; the inner side of the crown is smooth. The base height varies greatly, and depends on the separate position in the exoskeleton, as well as on the ontogenetic development stage of the scale. The pulp depression is comparatively long and narrow; deep in most of the scales, shallow and less expressed in older ones.

Pinnal scales are narrow, sharp and pointed, with a prominent base, growing in the same axis as the posterior end of the crown. The crown is rounded, pointed, and bobbin-shaped. The ribs of the crown are sharp, as in the cephalo-pectoral scales. Usually there is only one central rib on the top surface of the crown, and two pairs of lateral ribs on both sides below (Fig. 4W-Z). In cases where the crown and the base retain the same longitudinal axis, the crown is always wider than the base, with lateral ribs inclining towards the ventral side of the crown, and fusing on the pointed posterior end. The base is bobbin-shaped (Fig. 4W-Z). Both the crown and the base are slightly convex. 


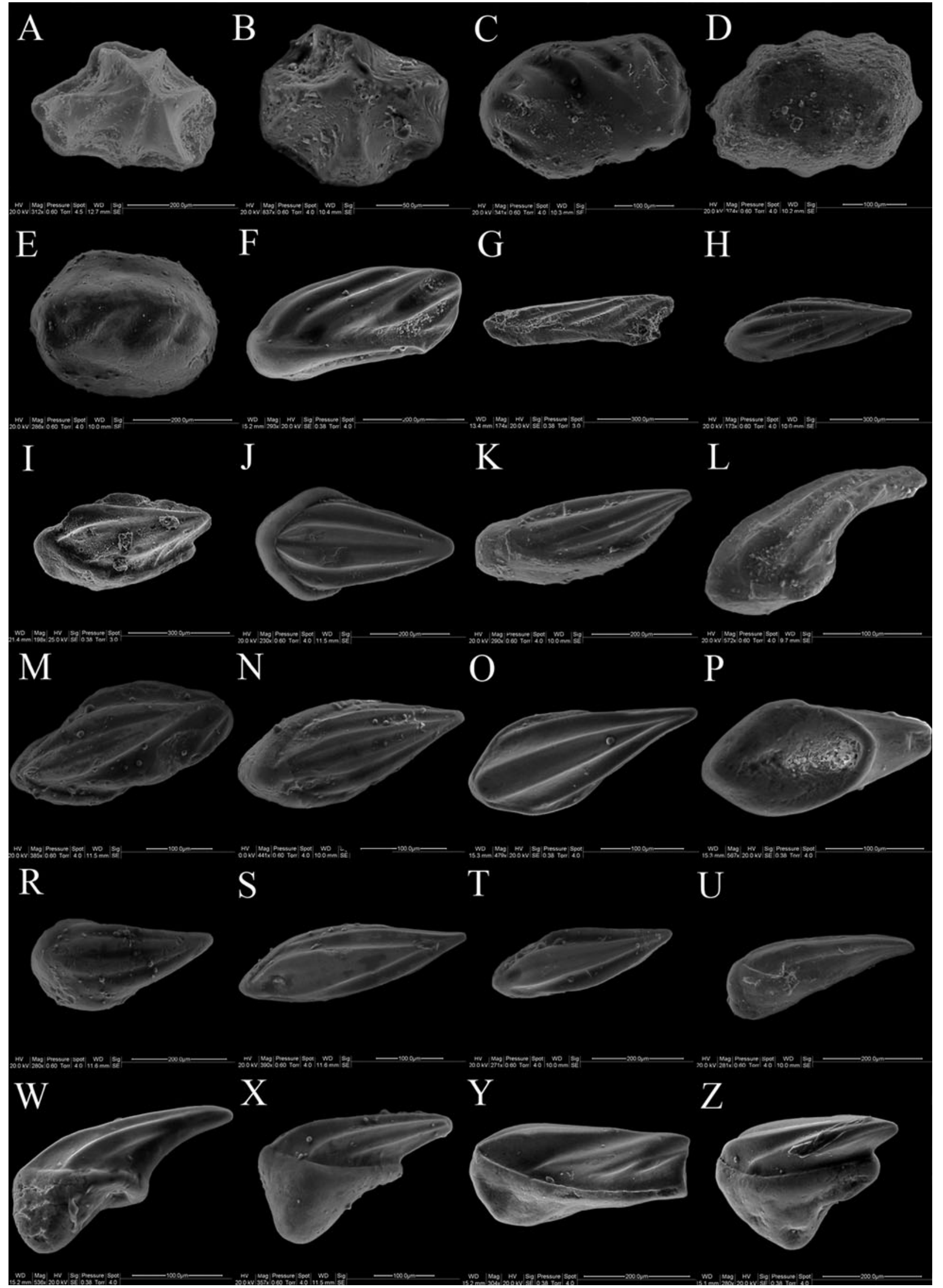

Figure 4 Loganellia sibirica (Karatajūtè-Talimaa, 1978). (A-D) Rostral scales: (A) 10-260; (B) 10-261; (C) 10 262; (D) 10-263, basal view. (E-H) Cephalo-pectoral scales: (E) 10-264; (F) 10-265; (G) 10-266; (H) 10-267. (I-U) Postpectoral and precaudal scales: (I) 10-268; (J) 10-269; (K) 10-270; (L) 10-271; (M) 10-272; (N) 10273; (O) 10-274; (P) 10-275, basal view; (R) 10-276; (S) 10-277; (T) 10-278; (U) 10-279. (W-Z) Pinnal scales: (W) 10-280; (X) 10-283; (Y) 10-284; (Z) 10-282. Lower Silurian, Lower Llandovery, Moyerocanian Regional Stage, Melichan Formation, Niuya-Beresovo district, Niuya-Beresovo subregion, East Siberia, Russia; and Lower Silurian, Lower Llandovery, Moyerocanian Regional Stage, lower Balturino Formation, Balturino district, Balturino subregion, East Siberia, Russia. 
Histology. The dentine tubules are thin, tightly packed and branch irregularly. The pulp canal is not developed. Significantly thicker dentine tubules or enlarged lacunae are not present, but some indistinct terminate lacunae can be developed near the depression of the base (Fig. 8B). However, in most cases, thin dentine tubules slightly widen and open straight onto the ventral side of the scale, particularly arround the depression of the base. The base, particularly if well developed, often has distinct Sharpey's fibres (Fig. 8B).

Comparison. Morphological and histological evidence suggest a close relationship between $L$. sibirica and $L$. asiatica scales. Both of the species represent the same histological type of irregular thin tubule dentine, with the absence of a pulp canal. The external constitution of their postpectoral and precaudal scales are particularly similar, as is the average size of the scales, which is also similar in the case of the type species $L$. scotica. Nevertheless, the scales of $L$. sibirica are significantly more elongated as compared to most of the other loganiid thelodont scales, with the exception of the strongly elongated scales of L. exilis Märss et al. (2002) and L. prolata Märss et al. (2002).

\section{Loganellia tuvaensis (Karatajūtè-Talimaa, 1978)} (Figs 5, 8E, F)

Complemented synonymy list after Blom 1999:

1978 Logania tuvaensis Karatajūtè-Talimaa, pp 76-79, Pl. XVIII, 1-6; Pl. XIX, 1-13; fig. 18: 1-3; fig. 19: 7.

1986 Loganellia cf. L. tuvaensis; Turner \& Peel, pp 82-84, fig. $3, \mathrm{D}, \mathrm{E}$

1997 Loganellia tuvaensis (Karatajūtè-Talimaa); KaratajūtèTalimaa, p. 2; p. 11, fig. 7d; p. 12, fig. 8g.

1999 Loganellia cf. L. tuvaensis; Blom, pp 15-17, partim, fig. 5, A-K, N, O; non fig. 5, L, M.

Holotype. LGI T-395, body scale, Karatajūtè-Talimaa 1978, Pl. XVIII, fig. 1.

Type locality and horizon. Elegest locality, central Tuva, Russia; Upper Silurian, Pridoli, Pitchi-Shui Formation, Elegest outcrop, sample Nr. 236 (Karatajūtė-Talimaa 1978).

Material. More than 600 well-preserved scales; collection series number LGI T; of which LGI T-609 to LGI T-632 are pictured by SEM; and LGI T-183 as thin sections.

Geological and geographical range. Lower Silurian, Upper Wenlock, Dashtygoi Regional Stage, Dashtygoi Formation; Elegest and Kadvoi localities, central Tuva, Russia. It is also known from the Upper Silurian (Ludlow and Pridoli) of central Tuva.

Emended diagnosis (complemented after Märss et al. 2007). Medium-sized scales $(0.4-1.0 \mathrm{~mm}$. long, and $0.2-0.5 \mathrm{~mm}$. wide), regularly rhomboid, sagittate in shape, with characteristic flat and saggy surface of the very low crown. The crown edges are even and smooth, with an exception of the anterior rim, which is often marked by one or few shallow notches. The lateral segments are narrow and indistinct, flanging the flat median part of the crown. Usually scales have only one pair of lateral segments. The base is convex and comparatively regular in its height, anterior part sometimes being slightly higher. The pulp depression is situated in the middle of the base, often overgrown in the older scales. Dentine tubules are thin, branching irregularly, and concentrated posteriorly in the crown; some odd wider tubules are present. Sharpey's fibres are well expressed.

Description. Morphology. Rostral scales are round, rarely more oval or rhomboid (Fig. 5A-D), which is unusual considering the rostral scales of the other loganiid species. Sometimes two or three rostral scales grow-up together and have a joint base, or even a joined crown, if scales fuse together at an early enough stage of their development. This may occure due to their special function in the rostral part of the animal. The crown is usually low, with equaly notched edges; the notches are not very deep. The base is rather shallow in young scales, and becomes higher in the older scales; a wide pulp depression is located in the middle of the ventral side of the scales.

Cephalo-pectoral scales are elongated, oval, sometimes slightly rhomboid and oak-leaf-like, with a slightly pointed posterior end of the crown (Fig. 5E-G). The base is usually low. The pulp depression is large and oval.

Postpectoral and precaudal scales are distinctly rhomboid and sagittate in shape; they may be regular rhomboid or strongly elongated (Fig. 5H-U). The crown has a characteristic flat surface and a very plane low crown. The edges of the crown are smooth and even, except in the anterior part of the crown, where it usually has one discriminate wedge-shaped notch or a few shallow notches. The single distinct wedgeshaped notch on the side of the anterior rim of the crown is very common (Fig. 5R, U). The lateral segments are indistinct and very narrow (usually one pair, rarely two) lining the median part of the flat rhomboid crown. Some scales are extremely elongated and narrow (Fig. $5 \mathrm{~N}, \mathrm{O}$ ). The base is medium to high in older scales, comparatively regular in its thickness, convex and slightly bulging in the anterior part. The pulp depression is much less distinct than in the rostral and cephalo-pectoral scales, and often overgrown in the older scales.

Pinnal scales are irregularly rhomboid, with a wider anterior and an elongated and pointed posterior part of the crown. The base is usually high, most likely corresponding to a deep implanting in soft tissues, according to the special functions of the scales. The base is wide and obtrudes the crown in the anterior part of the scale (Fig. $5 \mathrm{~W}-\mathrm{Z}$ ).

Histology. Dentine of the scales is composed of thin and irregularly branching dentine tubules, opening directly to the base, or on the surface of the pulp depression, as the central pulp canal is not developed. Thin dentine tubules are numerous, branching in the central and posterior parts of the scale (Fig. 8E, F). The neck area is reduced, and therefore dentine tubules align more regularly towards the base and become perpendicular to the crown surface; some of them may get slightly wider and form small lacunae (Fig. 8F). Sharpey's fibres stretch perpendicular to the base surface and are distinct, particularly in the older scales.

Comparison. The lateral ribs on the sides of the crown, rounded rostral scales with typical sculpture, oak-leaf shaped cephalo-pectoral scales, and low neck of the body scales - all are very characteristic features of the genus Loganellia (see e.g., Märss et al. 2007). However, L. tuvaensis is highly distinct from the other species of the genus, because of the low crown with a flat surface and even rims, and a highly reduced neck. L. tuvaensis is the only species with a flat and smooth rhomboidal crown, and a single pair of thin lateral ribs. Most of the other species of Loganellia possess much narrower crowns, with a characteristic wedge-shaped trough along the midline, and often two or three pairs of lateral ribs.

\section{Talimaalepis Žigaitè, 2004}

Emended diagnosis (modified after Žigaitė 2004). Scales are medium size, flattened and elongated, rectangular to oval in shape. The crown possesses several pairs of sharp longitudinal ridges, of which a median pair is much longer, and divides the crown into a long central part, and paired shorter lateral wings. The neck is reduced. The wedge-shape base has a horizontal thalamus-shaped anterior part, often with a spur-like outgrowth, and a long narrow anchoring posterior process, 


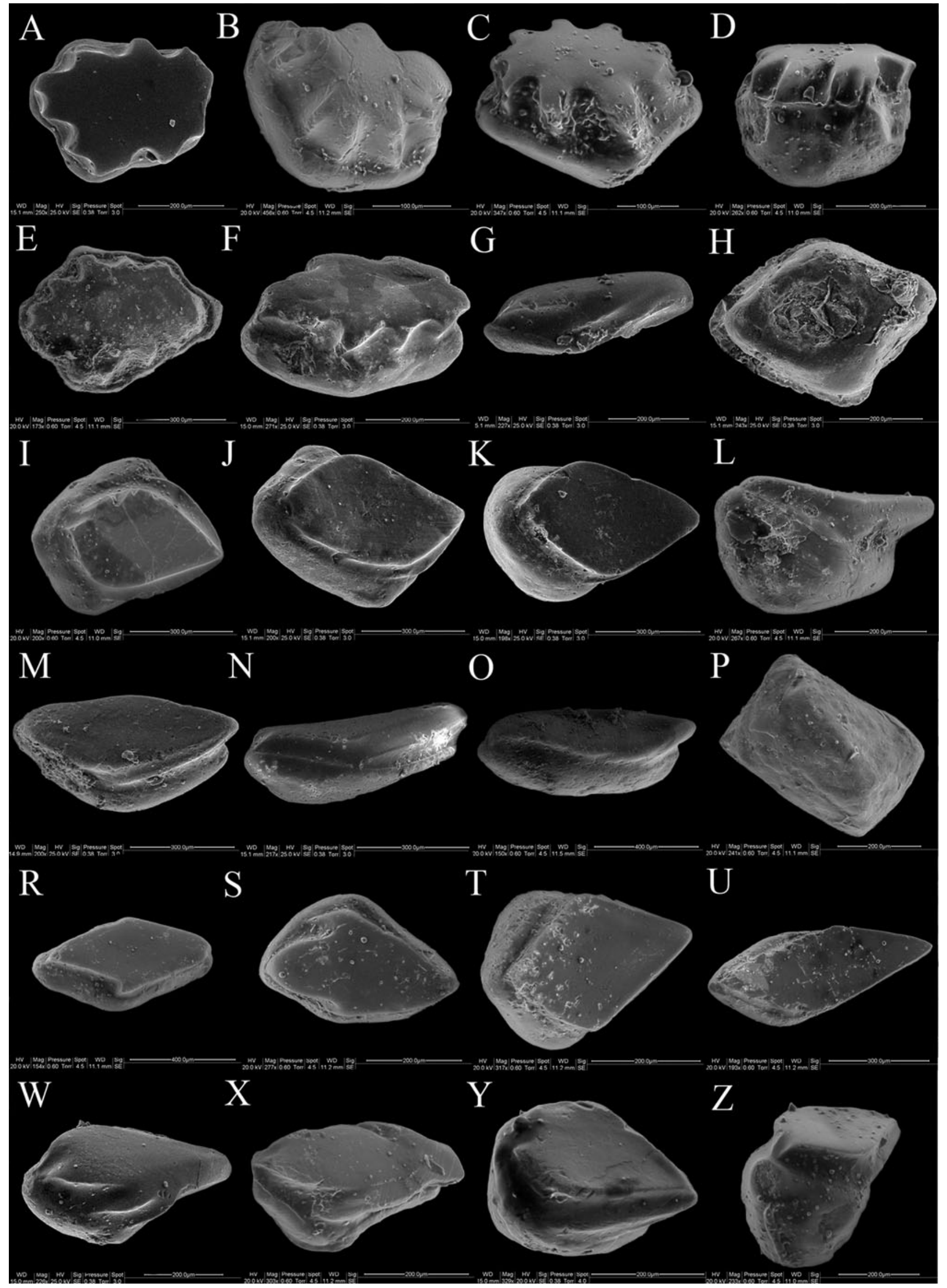

Figure 5 Loganellia tuvaensis (Karatajūtè-Talimaa, 1978). (A-D) Rostral scales: (A) T-609; (B) T-610; (C) T611; (D) T-612. (E-G) Cephalo-pectoral scales: (E) T- 613; (F) T-614; (G) T-615. (H-U) Postpectoral and precaudal scales: (H) T-616, basal view; (I) T-617; (J) T-618; (K) T-619; (L) T-620; (M) T-621; (N) T-622; (O) T623; (P) T-624, basal view; (R) T-625; (S) T-626; (T) T-627; (U) T-628. (W-Z) Pinnal scales: (W) T-629; (X) T630; (Y) T-631; (Z) T-632. Lower Silurian, Upper Wenlock, Dashtygoi Regional Stage, Dashtygoi Formation, Elegest and Kadvoi localities, central Tuva, Russia. 
descending at an angle. The pulp opening is located just behind the vertical projection of the base. The internal structure of the scales is composed of thick tubule dentine. The dentine comprise thin and thick tubules, which extend regularly, getting narrower towards the surface of the crown, but widen and anastomose pulpwards. No scales with sensory line openings (i.e., pores; see Karatajūtè-Talimaa 1978) have been found.

Type species. Talimaalepis rimae Žigaitè, 2004. Species: Talimaalepis kadvoiensis (Karatajūtè-Talimaa, 1978) Źigaitė 2004 comb. nov.

\section{Talimaalepis rimae Žigaite 2004 comb. nov} (Figs 6, 9D)

1978 ?Logania kadvoiensis, Karatajūtè-Talimaa; pp 82-86; p. 295, Pl. XIX, fig. 14; p. 298, Pl. XXII, figs 1-6; p. 230, partim fig. 15: 5-6; non fig. 15: 7-9.

1978 Loganellia asiatica, Karatajūtè-Talimaa ; pp 73-76 ; Pl. XXI, fig. $17 \mathrm{a}, \mathrm{b}$.

1991 ?Loganellia kadvoiensis; Turner; p. 111.

1991 Helenolepis sp. "supposed", Turner; p. 111.

1999 Helenolepis? kadvoiensis, Turner; p. 63, fig. 8.9.

2004 Talimaalepis rimae gen. et sp. nov., Žigaite; pp 158-165; p. 160, partim Pl. I, figs E-J, L, Q; non Pl. I, figs A-D, K, M-R, S-Z; p. 162, partim Pl. II, figs D, E, G, N, O; non $\mathrm{Pl}$. II, figs $\mathrm{A}-\mathrm{C}, \mathrm{F}, \mathrm{H}-\mathrm{M}$.

2007 Talimaalepis kadvoiensis (Karatajūtè-Talimaa, 1978) Žigaitė comb. nov.; Märss et al., pp 60-61, partim, fig. 57, D-G; non fig. 57, A-C, H-M.

Holotype. LGI M-1/224, cephalo-pectoral scale, NW Mongolia, sample 1009/3, Žigaite 2004, p. 160, pl. 1, fig. E. (Fig. $5 \mathrm{R})$.

Paratype. LGI T-599, postpectoral scale, Tuva, Kadvoi 662 (Fig. 6M).

Type locality and horizon. South-east slope of mount Chargat, $80 \mathrm{~km}$ north from lake Khara-Ubs-Nuur, northwest Mongolia; Lake Basin outcrop Nr. 20, sample P-16/3; Chargat Formation, Salhit Regional Stage, upper Llandovery-Wenlock, Lower Silurian.

Paratype locality and horizon. Kadvoi locality, central Tuva, Russia; Kadvoi locality, sample Nr. 662; Angatchi Formation, Angatchi Regional Stage, uppermost Llandovery, Lower Silurian.

Material. Over 400 scales of good preservation; collection series numbers LGI M-1 and LGI T; of which LGI M-1 214, 221-224, 231-233, 248, as well as LGI T 901-904, 912, 914918, and T 920-926 are photographed by SEM; and LGI M-1 28 as thin sections.

Geological and geographical range. Lower Silurian, Upper Llandovery, Agidyan Regional Stage, Omnutakh Formation; Turukhansk district, North Prienissey subregion, East Siberia, Russia. Lower Silurian, Wenlock, Salhit Regional Stage, Chargat Formation; Lake Basin outcrop Nr. 20, Chargat locality, Lake Khar-Us, north-west Mongolia (sample P 16/3). Lower Silurian, Wenlock, Salhit Regional Stage, Chargat Formation; Lake Basin outcrop Nr. 21, Chargat locality, Lake Khar-Us, north-west Mongolia (samples 1009/1 and 1009/3). Lower Silurian, Upper Wenlock, Angatci Regional Stage, Angatchi Formation; outcrop Kadvoi, central Tuva, Russia (Kadvoi 660-1). Lower Silurian, Wenlock, Khakomian Regional Stage, Usas Formation; Kochumdek district, Pritunguska subregion, East Siberia, Russia. Lower Silurian, Wenlock, Khakomian regional stage; Balturino Formation; Balturino district, Irkutsk subregion, East Siberia, Russia (sample Balturino 135-63). Lower Silurian, Upper Wenlock, Dashtygoi Regional Stage, Dashtygoi Formation; outcrop
Kadvoi, central Tuva, Russia (Kadvoi 662-663). Lower Silurian, Upper Wenlock, Dashtygoi Regional Stage, Dashtygoi Formation; outcrop Elegest, central Tuva, Russia (Elegest 226).

Emended diagnosis (modified after Karatajūtè-Talimaa 1978 and Žigaite 2004). Scales are of medium size $(0.3-1.4 \mathrm{~mm}$. long, and $0.1-0.5 \mathrm{~mm}$. wide), flattened, elongated and rectangular to oval in shape, with pronounced parallel longitudinal ridges (often six or more), and a narrow indistinct median trough. Rostral and cephalopectoral scales are bobbin-shaped, the longitudinal ridges are oblique, converging towards the pointed end of the crown. The median pair of longitudinal ribs is usually significantly longer than the lateral pairs of longitudinal ribs, dividing the crown into a longer central part and shorter lateral parts. The troughs separating the central and the lateral parts of the crown are sharper and deeper than the central trough. The neck is not well expressed. The base is wedge-shaped, with a thalamus-like horizontal crownrimming part, a distinct spur-like outgrowth on its anterior part, and a long narrow anchoring process descending downwards at an obtuse or right angle. The pulp opening is wide, located just behind the vertical projection of the base. Thick dentine tubules and one single pulp canal characterise the internal structure of the scales. The dentine tubules extend regularly, getting thinner towards the surface of the crown, thickening and anastomosing pulpwards. Any openings which may correspond to the pores of a sensory line canal system, have not been observed.

Description. Morphology. Rostral scales are round and bunchy; their crown is high, with eight, 10 or 12 sharp ridges, converging towards the uplifted central point, creating a notched stack-shape (Fig. 6A-D). The ridges are similar in size and sharpness, and spread uniformly around the crown, as do the troughs between them. The base is very low, repeating the shape and slightly obtruding the crown, with a very wide pulp depression.

Cephalo-pectoral scales are bobbin-shaped, elongated and roundish, with at least six to 12 or more oblique and sharp crown ridges, converging towards the high pointed posterior end of the crown. The ridges form a sharp crest, and converge towards the median-posterior part of the crown, which extends towards the pointed posterior end (Fig. 6E-H). The base is small, slightly wider and obtruding the crown, but not yet fully thalamus-shaped, as it is in the postpectoral scales (see below). In younger scales, the posterior long narrow anchoring process of the base may not be completely developed, but in the older ones it is rather well expressed, descending downwards at an obtuse or right angle. A distinct spur-like outgrowth on the anterior part of the base is also visible (Fig. 6A-G).

Postpectoral scales are comparatively large, flattened, elongated and rectangular to oval in shape. Longitudinal ridges are discriminately parallel, sharp, bunchy, having a rounded crest shape. The median trough is narrow, straight and indistinct. At least three pairs of lateral ridges are present, and the troughs separating them from the central part of the crown are sharper and deeper than the central trough itself (Fig. 6I-R). The median pair of longitudinal ribs is usually significantly longer than the lateral pairs of longitudinal ribs, dividing the crown into a longer central, and shorter lateral parts on the sides of the crown. The crown is implanted in a smooth, thalamus-like base (Fig. 6K, M, N, T), the neck is reduced. The posterior edge of the crown is fine, sculptured, and overhangs the base. The base is wedge-shaped, composed of thalamuslike horizontal crown-rimming part, with a distinct spur-like outgrowth on its anterior part, and of a long narrow anchoring process, descending downwards at an obtuse, or right angle 


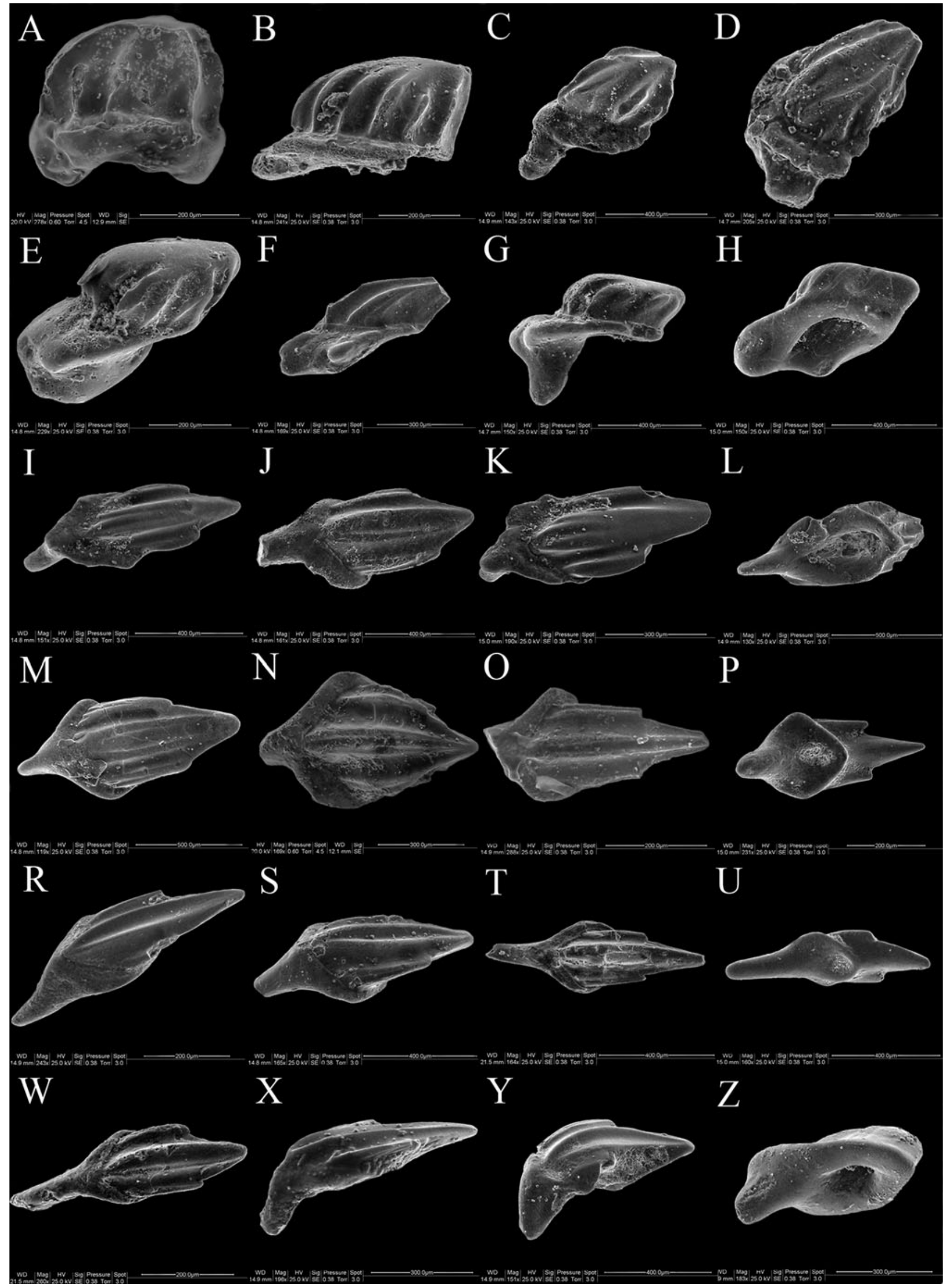

Figure 6 Talimaalepis rimae Žigaite 2004. (A-D) Rostral scales: (A) T-901; (B) T-902; (C) T-903; (D) T-904. (E-H) Cephalo-pectoral scales: (E) T-914; (F) T-912; (G) T-915; (H) T-916. (I-R) Postpectoral scales: (I) M-1 232; (J) T-920; (K) T-921; (L) T-917; (M) M-1 233, paratype; (N) T-922; (O) M-1 248; (P) M-1 231; (R) M-1 224, holotype. (S-W) Precaudal scales: (S) T-294; (T) M-1 214; (U) M-1 221; (W) T-923. (X-Z) Pinnal scales: (X) T925; (Y) T-926; (Z) T-918. Lake Basin outcrop Nr. 21, Chargat locality, Lake Khar-Us, north-west Mongolia (samples 1009/1 and 1009/3). 
(Fig. 6I, K, R, P). The pulp opening is wide, located just behind the vertical projection of the base.

Precaudal scales are narrower and less flat in comparison to the postpectoral ones. The crown sculpture is still similar to that of postpectoral ones, possessing sharp and parallel longitudinal ridges and narrow uniform troughs. Although the number of lateral ridges is smaller than in the postpectoral scales, usually only four (or two pairs) of ridges are present (Fig. 6S-W). Despite this, and even with a single pair of lateral longitudinal ribs, the crown is still clearly divided into a longer median part and shorter side part of paired lateral wings, as in the postpectoral scales. The median section is often elevated in comparison to the lateral ridges. The posterior narrow process of the base is still long, but much more horizontal, sometimes stretching within the same plain, and not forming an angle with an anterior thalamus-like part of the base (Fig. 6T, W).

Pinnal scales are quite robust, elongated, slightly bobbinshaped and not flattened. Sharp longitudinal ridges are still present, forming parallel narrow troughs. The base is comparatively uniform, the flat anterior part is reduced, and the posterior process is comparatively massive, descending at almost a right angle in respect to the surface of the crown (Fig. 6X-Z).

Histology. Thick dentine tubules are present, getting thinner towards the surface of the crown, though gradually wider and anastomosing towards the single pulp canal. In the central part of the scale, usually several thick dentine canals enter the pulp canal (Fig. 9D). No openings (i.e. pores) belonging to the sensory line canal system have been observed.

Comparison. Scales are more rectangular, and wider in comparison to those of the other species of Talimaalepis, i.e. T. kadvoiensis (see below). The longitudinal ribs are parallel, forming sharp, narrow and parallel troughs instead of a distinct wide rhomboid central trough as that of $T$. kadvoiensis. Also, the number of longitudinal ridges is much higher than that of $T$. kadvoiensis, especially in the case of postpectoral scales. The longitudinal ridges themselves are bunchy, having the shape of a rounded crest, in contrast to simply sharp brims, as in the T. kadvoiensis scales. The base of $T$. rimae has a more or less well expressed outgrowth on its anterior part, which is not the case for the base of T. kadvoiensis.

\section{Talimaalepis kadvoiensis (Karatajūtè-Talimaa, 1978) Žigaitė} comb. nov.

(Figs 7, 8G, H, 9E)

1978 ?Logania kadvoiensis, Karatajūtė -Talimaa; pp 82-86; p. 288, partim Pl. XII, figs 1a, 3, 6, 7, 8, 9 a, b; non Pl. XII, figs 1b, 2, 5; p. 289, partim Pl. XIII, fig. 4 a, b; non Pl. XIII, figs 3a, b, c, 5, 6; p. 230, partim fig. 15: 7-9; non fig. 15: 5-6.

1991 ?Loganellia kadvoiensis, Turner; p. 11.

1991 Helenolepis sp. "supposed", Turner; p. 111.

1999 Helenolepis? kadvoiensis, Turner; p. 63, fig. 8.9.

2004 Talimaalepis rimae gen. et sp. nov., Žigaite; pp 158-165; p. 160, partim, Pl. I, figs A, C, D, K, M-R, S-Z; non Pl. I, figs B, E-J, L, Q; p. 162, partim, Pl. II, figs C, I, J-M; non, $\mathrm{Pl}$. II, figs $\mathrm{A}, \mathrm{B}, \mathrm{D}-\mathrm{H}, \mathrm{N}, \mathrm{O}$.

2007 Talimaalepis kadvoiensis (Karatajūtè-Talimaa, 1978) Žigaitè comb. nov. ; Märss et al., pp 60-61, partim, fig. 57: A-C, H-M; non fig. 57, D-G.

Holotype. LGI T-059, described as a body scale by Karatajūtè-Talima (1978), p. 288, Pl. XII, fig. 9a, b; re-attributed here to a postpectoral scale (Märss 1986).

Paratype. LGI M-1/206, postpectoral scale, NW Mongolia, sample Nr. 1009/4 (Fig. 7J).
Type locality and horizon. Kadvoi locality, central Tuva, Russia; Kadvoi outcrop, sample Nr. 664; Dashtygoi Formation, Dashtygoi Regional Stage, Lower Ludlow, Upper Silurian.

Paratype locality and horizon. South-east slope of mount Chargat, $80 \mathrm{~km}$ north from lake Khara-Ubs-Nuur, northwest Mongolia; Lake Basin outcrop Nr. 21, sample S-1009/4; Chargat Formation, Salhit Regional Stage, Upper LlandoveryWenlock, Lower Silurian.

Material. Over 200 scales of good preservation; collection series numbers LGI M-1 and LGI T; of which LGI M-1 200, 2007, 226, 242 and 280-289, as well as LGI T 944-952, are photographed by SEM; and LGI M-1 27 and M-1 29 as thin sections.

Geological and geographical range. Lower Silurian, Middle Llandovery, Khaastyrian Regional Stage, Talikit Formation; Ilim district, Irkutsk subregion, East Siberia, Russia (sample 141-26). Lower Silurian, Upper Llandovery, Agidyan Regional Stage, Balturino Formation; Balturino district, Irkutsk subregion, East Siberia, Russia (samples Balturino 135-47/46). Lower Silurian, Upper Llandovery, Kyzyl-Tchiraa Regional Stage, Kyzyl-Tchiraa Formation; outcrop Kyzyl-Tchiraa, central Tuva, Russia (samples 702, 271R, 253R). Lower Silurian, Wenlock, Salhit Regional Stage, Chargat Formation; Lake Basin outcrop Nr. 21, Chargat locality, lake Khara-UbsNuur, northwest Mongolia (samples 1009/2 and 1009/4). Lower Silurian, Upper Wenlock, Angatci Regional Stage, Angatchi Formation; outcrop Kadvoi, central Tuva, Russia (sample Kadvoi 660-4). Lower Silurian, Upper Wenlock, Dashtygoi Regional Stage, Dashtygoi Formation; outcrop Elegest, central Tuva, Russia (sample Elegest 226). Lower Silurian, Upper Wenlock, Dashtygoi Regional Stage, Dashtygoi Formation; outcrop Kadvoi, central Tuva, Russia (sample Kadvoi 664). It is also known from the Silurian-Devonian boundary (PridoliLochkovian), the uppermost Tauganteli and lowermost Khondergei Regional Stages, the uppermost Khondergei Formation; river Tchadan outcrop, Bazhyn-Alaak locality, central Tuva, Russia (sample 119).

Emended diagnosis (modified after Žigaitė 2004; Märss et al. 2007). Scales are of medium size $(0.3-1.2 \mathrm{~mm}$. long, and 0.2 $0.3 \mathrm{~mm}$. wide), flattened and elongated, oval or rhomboid in shape, with a discriminate central elongated rhomb-shaped trough. The longitudinal ridges are sharp, median pair is much higher than the lateral ones. The median pair of longitudinal ribs is significantly longer than the lateral pair, dividing the crown into longer central and shorter lowered lateral parts on the both sides of the crown. The rostral and cephalopectoral scales are rhomboid, with densely notched sides, and the crown surface is flat. Usually there is only one pair of underlying lateral longitudinal ribs, sometimes two pairs. The neck is reduced. The base is wedge-shaped, with a thalamus-like horizontal crown-rimming part, and a long narrow anchoring process, descending downwards at an obtuse angle. The pulp opening is narrow, located just behind the vertical projection of the base. Thick tubules are characteristic of the dentine of the scales. They extend regularly, being thin near the surface of the crown, and getting wider and anastomosing pulpwards. A single pulp canal is present. No pores of a sensory line canal system are present in any of the scales.

Remarks. This study, together with the revision of formerly described vertebrate microremains from the region, has revealed that the first descriptions of the taxon Logania? kadvoiensis by Karatajūtè-Talimaa (1978) include some scales which belong to the genus Helenolepis (Karatajūtė-Talimaa 1978; p. 288, Pl. XII, figs 1 b, 2, 5 and p. 289, Pl. XIII, figs 3a, b, c, 5, 6).

Description. Morphology. Rostral scales are rhomboid to oval in shape, with a massive base, which is usually larger than the crown (Fig. 7A-D). The edges of the crown are densely 


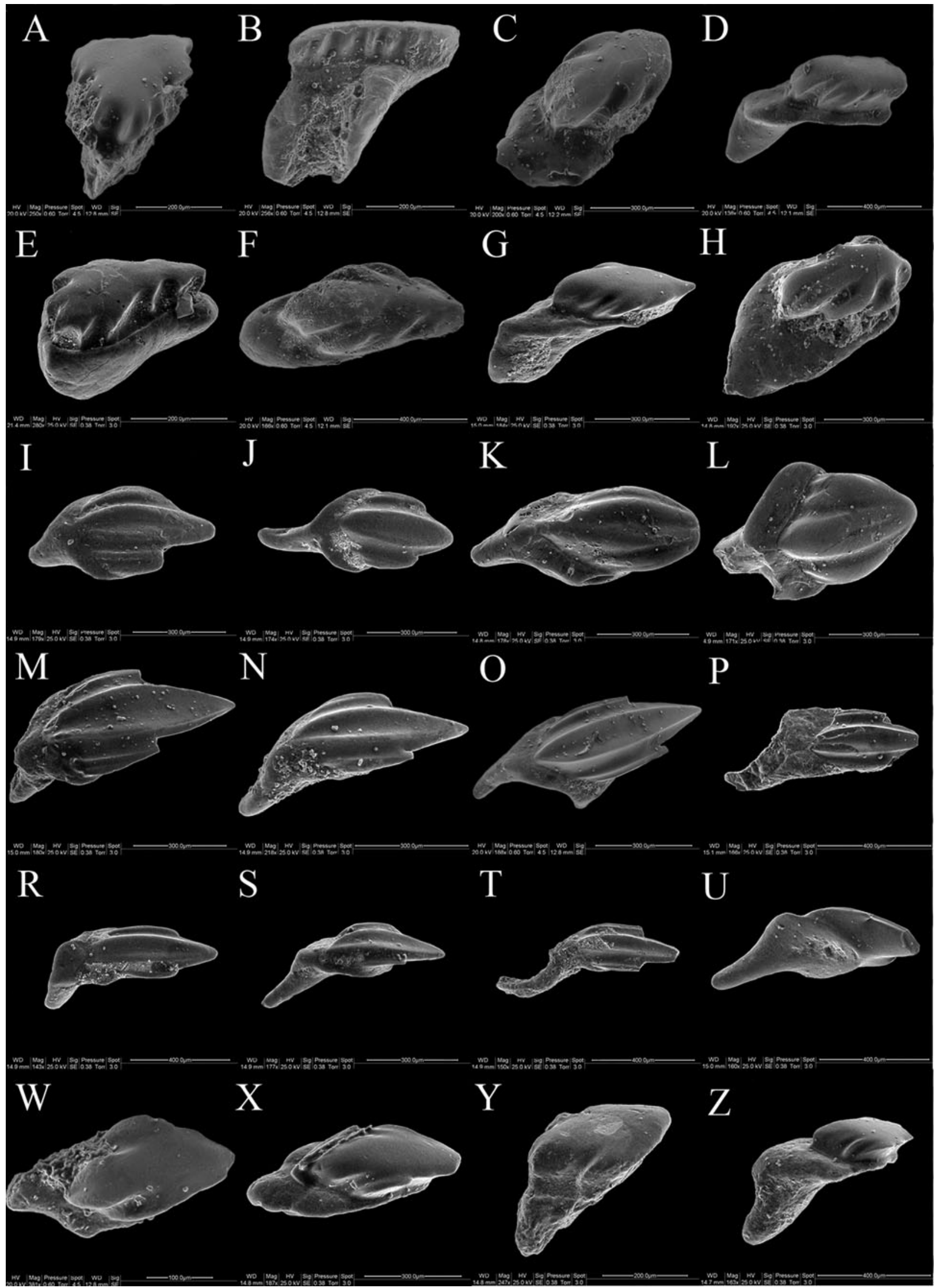

Figure 7 Talimaalepis kadvoiensis (Karatajūtè-Talimaa, 1978) Žigaite 2004 comb. nov. (A-D) Rostral scales: (A) M-1 280; (B) M-1 281; (C) M-1 288; (D) M-1 289. (E-H) Cephalo-pectoral scales: (E) M-1 242; (F) T-944; (G) T-945; (H) T-946. (I-P) Postpectoral scales: (I) M-1 282; (J) M-1 206, paratype; (K) M-1 283; (L) T-947; (M) M-1 207; (N) T-948; (O) T-950; (P) M-1 226. (R-U) Precaudal scales: (R) T-949; (S) T-951; (T) M-1 200; (U) T-952. (W-Z) Pinnal scales: (W) M-1 285; (X) M-1 284; (Y) M-1 287; (Z) M-1 286. Lower Silurian, Upper Llandovery, Kyzyl-Tchiraa Regional Stage, Kyzyl-Tchiraa Formation, outcrop Kyzyl-Tchiraa, central Tuva, Russia (samples 702, 271R, 253R); and Lower Silurian, Wenlock, Salhit Regional Stage, Chargat Formation; Lake Basin outcrop Nr. 21, Chargat locality, lake Khara-Ubs-Nuur, north-west Mongolia (samples 1009/2 and 1009/4). 
notched; the notches are slightly oblique, short and wide. The surface of the crown is smooth and lacks any kind of sculpture. The base is high and as wide as the crown, sometimes slightly obtruding the crown near its anterior rim.

Cephalo-pectoral scales are oval and elongated, with a comparatively high oak-leaf-like crown. The edges of the crown are densely notched, oblique, short and comparatively narrow. The base is wedge-shaped, comparatively large, with a distinct horizontal anterior part, and a long narrow anchoring posterior process, descending downwards at an obtuse angle (Fig. 7E$H)$. The thalamus-like anterior part of the base is not developed, due to the comparatively high crown.

Postpectoral scales are flattened and elongated, oval and slightly rhomboid, the crown is usually wider and longer than the base, with a shallow and wide rhomboidal central trough. The longitudinal ridges are sharp, the median pair being uplifted in comparison to the lateral ones. The median pair of longitudinal ribs is significantly longer than the lateral pairs, dividing the crown into a longer central and shorter lowered lateral parts on the both sides of the crown (Fig. 7I-P). The base is wedge-shaped, composed of two distinct parts - a thalamus-like horizontal one, rimming the anterior edges of the crown, and a long narrow anchoring posterior process, descending downwards at an obtuse angle (Fig. 7J, M, O). The pulp opening is small and narrow, located just behind the vertical projection of the base.

Precaudal scales are flattened, elongated and comparatively narrow. The crown usually does not have more than two pairs of longitudinal ridges, the median pair being longer and uplifted in comparison to the lateral ones, which form downstepping wings on both sides of the crown (Fig. $7 \mathrm{R}-\mathrm{U}$ ). The base is narrow, wedge-shaped, and is composed of two distinct parts: a thalamus-like horizontal part, rimming the anterior part of the crown, and a very long narrow anchoring posterior process, descending downwards at a very obtuse angle, or sometimes stretching nearly in the same plane as the crown (Fig. 7S, T).

Pinnal scales are elongated and slightly rhomboid, with a notched anterior rim of the crown, though longitudinal ridges are not distinct. Instead, some short ridgelets, following the notched crests of the anterior rim of the crown, are present. The posterior part of the crown itself is slightly uplifted and has a pointed end (Fig. $7 \mathrm{~W}-\mathrm{Z}$ ). The base is very high, wedgeshaped, with a smooth flat horizontal part, obtruding the anterior edges of the crown, and a long massive anchoring posterior process, descending downwards at an obtuse or right angle.

Histology. Thick dentine tubules are present. Near the surface of the crown, dentine tubules are narrow and branch regularly, but get gradually thicker and anastomosing towards the single pulp canal (Figs 8G, H, 9E). In the central part of the scale, several thick dentine canals enter a wide single pulp canal. The pulp canal occupies approximately two thirds of the crown length. No pores of a sensory line canal system have been observed in any of the scales.

Comparison. Scales are more rhomboid and oval than those of $T$. rimae. Only a few longitudinal ribs are present, sharply rimming the wide rhomboid median trough in between the central pair of longitudinal ridges. The median part of the crown is longer and uplifted in comparison to the short and low lateral wings, which is different from the uniform flattened scale pattern of $T$. rimae. The outgrowth on the anterior part of the base is not as distinct as it is in the case of $T$. rimae.

\section{Discussion}

Special attention should be given to the taxonomy of the genus Talimaalepis Žigaitè, 2004. The internal structure of its dermoskeleton shows an intermediate position between those of the genera Loganellia (Fam. Loganellidae) and Helenolepis (Fam. Phlebolepidae), as noted by Turner (1991, 1999). Two species of Talimaalepis are described in this work on the basis of morphological differences, while scale histology is considered as a generic or even higher taxonomic characteristic (see also Karatajūtė-Talimaa 1978, 1998; Märss et al. 2007). The presence of thick dentine tubules in Talimaalepis scales indicates a more complex internal structure of the dermoskeleton relative to loganelliid thelodonts, which contain thin dentine tubules only. However, on a morphological basis, Talimaalepis is slightly closer to loganelliids than to phlebolepidid thelodonts, and this is why we decided to keep the attribution of the genus to the family Loganelliidae, and to the order Loganelliiformes (see Märss et al. 2007, p. 60).

The attribution of Talimaalepis by Märss et al. (2007) to the family Loganelliidae appears to be disputed by the histology of the scales, as loganelliids do not possess any wider dentine tubules, which are the characteristic feature of the genus Talimaalepis. However, the presence of one single pulp canal typical for the genus Loganellia, as well as sparse anastomoses of usually straight dentine canals, makes the internal structure of Talimaalepis close to that of the loganelliid thelodonts. The robust crown with no posterior appendages is the primary diagnostic feature of the family Loganelliidae, though this feature is not observed in Talimaalepis, where the ridges of the crown terminate as three posterior spines (Figs 6I-W, 7I-U). Moreover, well-defined, thick dentine canals opening into more than one pulp canal, characteristic of Talimaalepis, is the diagnostic feature of the genus Helenolepis, and has not been observed in any scales of loganelliid thelodonts. Nevertheless, Helenolepis scales have several pulp canals (usually more than three, see Fig. 9A-C), in accordance with the number of crown segments (Karatajūtè-Talimaa 1978, p. 236, fig. 14). This is not the case in Talimaalepis scales, which have one single pulp canal present despite the crown's sculpture. On the basis of these pronounced histological differences, Talimaalepis is distinct from both Loganellia and Helenolepis. However, this work suggests rejection of the previous assignation of Talimaalepis to the family Phlebolepididae Berg 1940 (Žigaite 2004, p. 159), together with helenolepids, on the basis of similar histology and the presence of sensory line canal pores. Previously described pores of the sensory line canal in the scales of Talimaalepis (Žigaite 2004, p. 162, pl. 2, fig. H), which are diagnostic to the family Phlebolepididae, have not been confirmed in this study. Nevertheless, it is necessary to admit that some helenolepid scales share strong morphological similarities to the scales of both of the Talimaalepis species. Some of the rostral scales and pinnal scales on the edges of fins in both of the Talimaalepis species are very similar to those of Helenolepis, especially to those of Helenolepis obruchevi Karatajūtè-Talimaa, 1978, sharing an extremely high vertical anchoring posterior process of the base in older scales. The main difference in the external structure of these scales would be the pattern of the anterior crown notches - Talimaalepis has oblique, not very deep and slightly wider notches (Figs 6G, 7D, Z), while Helenolepis has straight, very narrow and deep-cutting notches, which are also more numerous in Helenolepis scales (Märss et al. 2007, fig. 81F, G, J).

In addition, significant morphological similarities exist between Talimaalepis and some shieliids, Shielia taiti (Stetson 1931) in particular (see Märss \& Ritchie 1998, figs 27A, 30A, B, 31). The presence of a similar wedge-shaped base with a horizontal thalamus-shaped anterior part, and a long, narrow anchoring posterior process, in both Talimaalepis and shieliid scales, deserves special attention. The uplifted median and lateral segments, the median having the shape of a rhomboid 

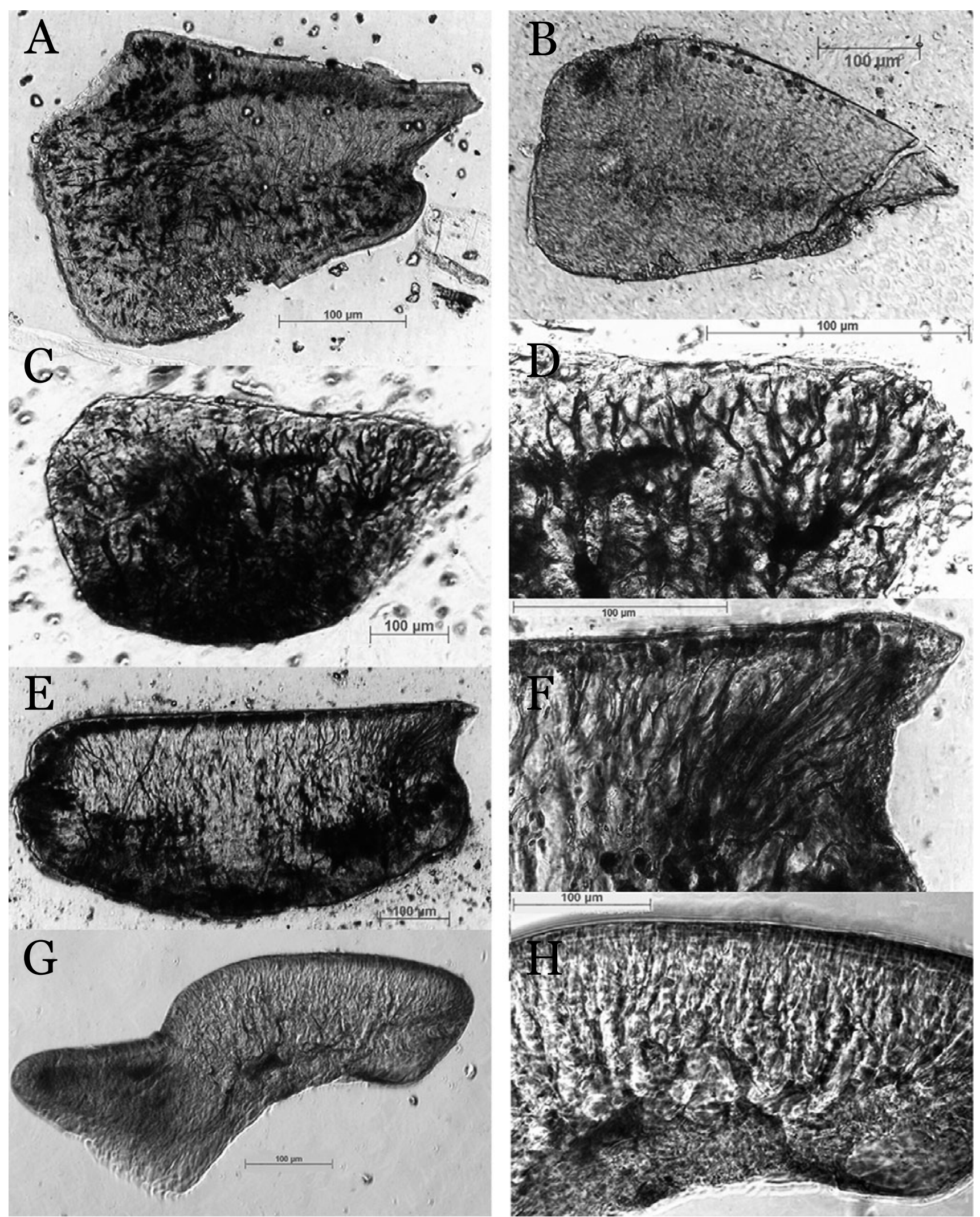

Figure 8 Cross-sections of scales: (A) Angaralepis moskalenkoae, LGI-10-TSnr-174; (B) Loganellia sibirica LGI-10-TSnr-488; (C, D) Loganellia asiatica, LGI-T-TSnr-592; (E, F) Loganellia tuvaensis, LGI-T-TSnr-183; (G, H) Talimaalepis kadvoiensis LGI-M-1-TSnr-27.

trough, are common features of these two groups as well. Moreover, some species of genus Paralogania, such as $P$. consimilis Märss \& Karatajūtè-Talimaa, 2002 (see Märss et al. 2007, fig. 59G-H), and P. kaarmisensis Märss, 2003 (see Märss et al. 2007, fig. 59J), share a number of characters with Talimaalepis.
To conclude, Talimaalepis appears to be morphologically similar to loganelliids rather than to phlebolepidid thelodonts, and therefore in this work we keep the affiliation of the genus to the family Loganelliidae, and the order Loganelliiformes (see Märss et al. 2007, p. 60). 

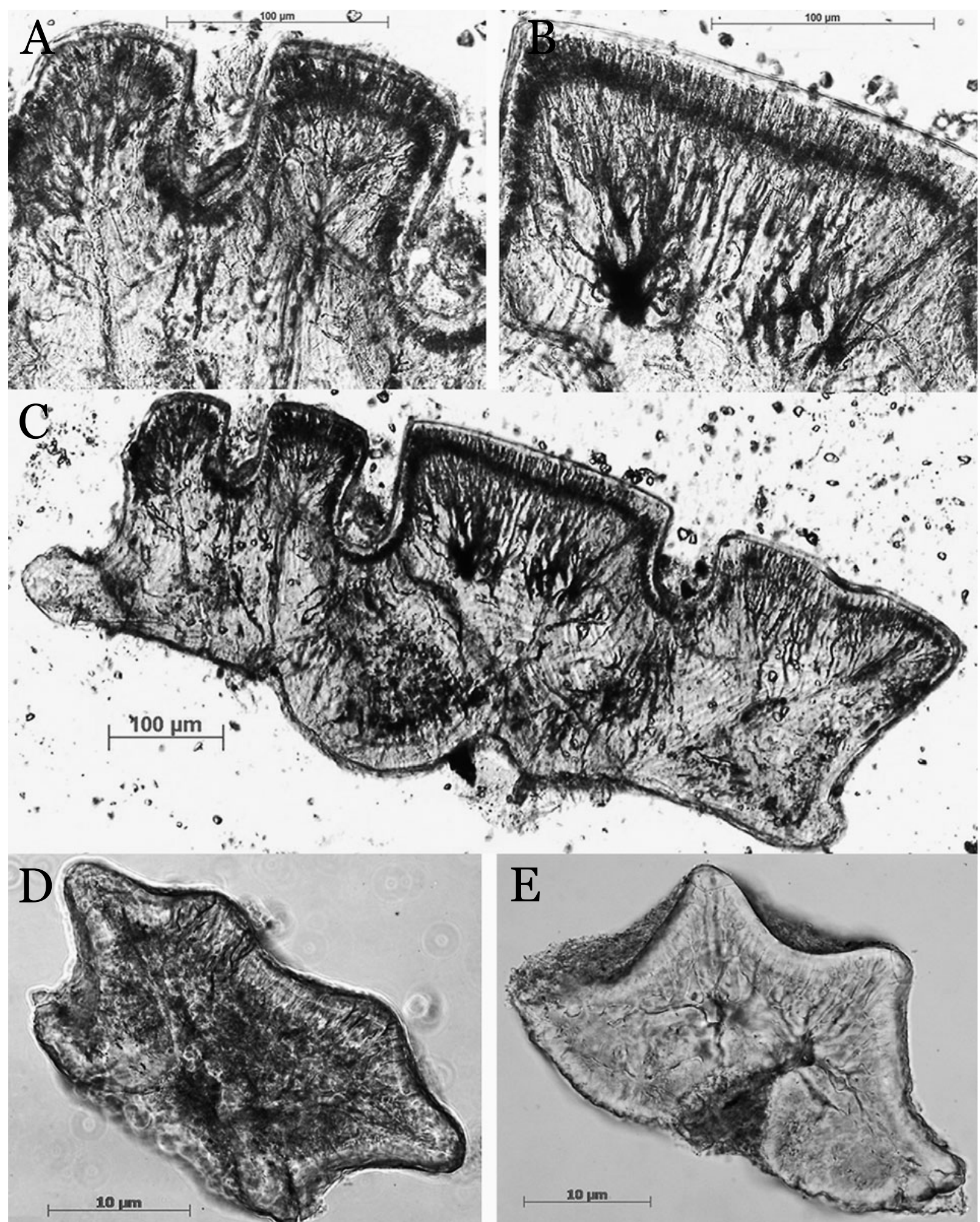

Figure 9 Cross-sections of scales: (A, B, C) Helenolepis obruchevi Karatajūtè-Talimaa, 1978, LGI-T-TSnr-102, (D) Talimaalepis rimae, LGI-M-1-TSnr-28; (E) Talimaalepis kadvoiensis, LGI-M-1-TSnr-29.

\section{Palaeobiogeographic context}

A separate palaeobiogeographical province for the Silurian vertebrates from central Asia and southern Siberia has already been assumed in earlier studies (Karatajūtè-Talimaa 1978; Blieck \& Janvier 1993; Žigaitè \& Karatajūtè-Talimaa 2008; Žigaitė et al. 2011; Žigaitė \& Blieck 2013). Following our work, the palaeobiogeographical distribution of thelodonts in the region confirms this. The distribution of endemic genera Angaralepis and Talimaalepis is restricted to the Lower Silur- ian localities discussed here. Loganellia is, however, cosmopolitan, although endemism is sustained at the species level of $L o$ ganellia: all three species, $L$. asiatica, $L$. sibirica, and $L$. tuvaensis are restricted to the region. In addition, $L$. tuvaensis is the only thelodont species that is limited to the Silurian of central Tuva. This could imply some degree of isolation of the Tuvan palaeobasin relative to the other epicontinental palaeoseas of the Siberian terrane. The reports of Loganellia $\mathrm{sp}$. cf. L. tuvaensis from the Upper Silurian-Lower Devonian (Pridoli-Lochkovian) of North Greenland, the Halls Grav locality and Monument, 
Hall Land, Chester Bjerg Formation deserve special attention, as significant evidence of ocean connections (Turner \& Peel 1986; Blom 1999; Žigaite \& Blieck 2006). Morphology and histology of the microremains suggest that $L$. cf. L. tuvaensis from North Greenland could be the same species as $L$. tuvaensis from central Tuva (excluding a few scales, described by Blom (1999), see synonymy above). This provides evidence for a possible close relationship between the Siberian and Laurentian palaebiogeographical provinces during the Late Silurian (Žigaite \& Blieck 2006; Žigaitè et al. 2011).

The discovery of Loganellia sibirica scales in the Lower Silurian of Tuva reported here supplements the previous finds in northwestern Mongolia and East Siberia, and indicates some connection between these palaeobasins. It is worth noting that the scales of $A$. moskalenkoae are often found together with those of $L$. sibirica, and they are both fairly abundant in the Lower Silurian of East Siberia, although A. moskalenkoae has been not found in any of the Silurian sections of Tuva or northwestern Mongolia. Turner \& Nowlan (1995) mention $L$. sibirica scales from the Llandovery of Quebec, and Loganellia cf. L. sibirica from the Llandovery of Nova Scotia. Unfortunately, in both cases pictures have not been provided; yet if confimed, this would significantly extend the geographical range of the species.

The territory of northwestern Mongolia, Tuva, and southern Siberia has been claimed to have occupied relatively high northern latitudes during the Early Silurian, suggesting an arid temperate climate and "cold-water" palaeoenvironment, according to palaeomagnetic data, and the presence of highlatitude faunal assemblages, e.g. the low-diversity (and by inference cold-water) Tuvaella fauna (Cocks \& Torsvik 2002, 2007; Tesakov et al. 2003). Such a northern palaeobasin does not, however, accord with the abundant and diverse record of Silurian vertebrates (Žigaite et al. 2011), which would rather indicate warm and productive low-latitude shelf environments (Blieck \& Janvier 1993; Žigaite et al. 2011). The stratigraphical levels of appearance of the thelodont taxa are comparatively early as well, considering the corresponding data from other palaeobiogeographical provinces, such as the Baltic Basin or the Canadian Arctic in the Early Silurian (KaratajūteTalimaa \& Brazauskas 1994; Märss et al. 2002, 2006). Most of the thelodont species and genera of the region have their first known occurrences in the Llandovery. In addition, they are accompanied by a variety of other early vertebrate taxa, such as acanthodians (Karatajūte-Talimaa \& Smith 2003), mongolepids (Karatajūtè-Talimaa et al. 1990) and putative galeaspids (Karatajūtè-Talimaa \& Žigaitè 2005, 2006; Žigaitė et al. 2011).

\section{Conclusions}

Two thelodont genera and six species from the Lower Silurian of NW Mongolia, Tuva, and S Siberia have been recognised as endemic. Loganellia is the only cosmopolitan thelodont genus in the region, although it stays endemic at the species level. Loganellia is also the most diverse in species, represented by $L$. asiatica (Karatajūtè-Talimaa 1978) L. sibirica (Karatajūtè-Talimaa 1978) and L. tuvaensis (Karatajūtè-Talimaa 1978). The species content of genus Talimaalepis Žigaite, 2004, so far known from a single species, has been revised, and two new species combinations are proposed and described here. The discovery of Loganellia sibirica scales in the Lower Silurian of Tuva, made during this study, questions the previously claimed palaeogeographical isolation of the Tuva terrane. To summarize, the endemism and overall distribution of thelodont taxa in the region are valuable palaeobiogeographical indicators. They show that the territory of East Siberia, Tuva and the northwestern part of Mongolia correspond to the same connected palaeobasin, and to a separate endemic palaeozoological province in the Early Silurian.

\section{Acknowledgements}

I am grateful to Dr. Tiiu Märss (Tallinn Institute of Technology, Estonia) for her great help and professional advice. This article was a part of my $\mathrm{PhD}$ project at the University Lille 1, France, and I would like to acknowledge my supervisor Dr. Alain Blieck (CNRS FRE 3298 "Géosystèmes", University Lille 1, France) for his support in all phases of this work. My sincere thanks to Dr. Valentina Karatajūtė-Talimaa (Vilnius, Lithuania) who generously provided the fossil material and crucial information on the localities. Many thanks to Prof. Per E. Ahlberg and Dr. Henning Blom (Uppsala University, Sweden) for their indispensible contribution to this article. Dr. Thomas Servais and Mr. Philippe Recourt (CNRS FRE 3298 "Géosystemès", University Lille 1, France) are sincerely acknowledged for the help with the SEM and high-resolution optical imaging. Prof. Daniel Goujet and Dr. Vincent Dupret have kindly allowed to study the articulated thelodont material for comparison in the National Museum of Natural History in Paris, and Prof. Ervīns Lukševičs (University of Latvia) helped greatly with his critical remarks on the manuscript. Many thanks to the reviewers Dr. Susan Turner, Dr. Robert Sansom and the anonymous reviewer for their valuable comments, which have greatly improved the quality of this paper.

This work is a contribution the French-Lithuanian International Scientific Collaboration Programme "Gillibert" (EGIDE, France), and the International Geoscience Programme IGCP 591 project.

\section{References}

Afanassieva, O. \& Janvier, P. 1985. Tannuaspis, Tuvaspis and Ilemoraspis, endemic osteostracan genera from the Silurian and Devonian of Tuva and Khakassia (USSR). Geobios 18(4), 493-506.

Berg L. S. 1940. [Systematics of modern and fossil fishes.] Russian Academy of Sciences, Proccedings of the Institute of Zoology 5, 87-517. [In Russian.]

Blieck, A. \& Janvier, P. 1993. Silurian-Devonian vertebrate biostratigraphy of Siberia and neighbouring terranes. In Long, J. A. (ed.) Palaeozoic vertebrate biostratigraphy and biogeography, 87103 (Chapter 5). London: Belhaven Press. [Also published by John Hopkins University Press, Baltimore, 1994].

Blom, H., 1999. Vertebrate remains from Upper Silurian-Lower Devonian beds of Hall Land, North Greenland. Geology of Greenland Survey Bulletin 182, 1-80.

Cocks, L. R. M. \& Torsvik, T. H. 2002. Earth geography from 500 to 400 million years ago: a faunal and palaeomagnetic review. Journal of the Geological Society 159(6), 631-44.

Cocks, L. R. M. \& Torsvik, T. H. 2007. Siberia, the wandering northern terrane, and its changing geography through the Palaeozoic. Earth-Science Reviews 82, 29-74.

Fredholm, D. 1990. Agnathan vertebrates in the Lower Silurian of Gotland. Geologiska Foreningens $i$ Stockholm Forhandlingar 112, 61-84.

Gross, W. 1967. Über Theledontier-Schuppen. Palaeontographica 127A, $1-67$.

Gross W. 1968. Porenschuppen und Sinneslinien des Thelodontiers Phlebolepis elegans Pander. Palaeontographica 42, 131-46.

Hairapetian, V., Blom, H. \& Miller, G. C. 2008. Silurian thelodonts from the Niur Formation, central Iran. Acta Palaeontologica Polonica 53(1), 85-95.

International Commission on Zoological Nomenclature (ICZN) 1999. International Code of Zoological Nomenclature, 4th edition. London: International Trust for Zoological Nomenclature. $306 \mathrm{pp}$.

Karatajūtè-Talimaa, V. N. 1978. [Silurian and Devonian Thelodonts of the USSR and Spitsbergen.] Vilnius: "Mokslas". 334 pp. [In Russian.] 
Karatajūtè-Talimaa, V. N. 1997. Taxonomy of loganiid thelodonts. Modern Geology 21, 1-15.

Karatajūtè-Talimaa, V. N. 1998. Determination Methods for the Exoskeletal Remains of Early Vertebrates. Mitteilungen aus dem Museum für Naturkunde zu Berlin, Geowissenschaftliche 1, 21-52.

Karatajūtè-Talimaa, V. N., Novitskaya, L. I., Rozman, K. S. \& Sodov, I. 1990. [Mongolepis - a new Lower Silurian elasmobranch genus from Mongolia.] Paleontologicheskiy Zhurnal 1, 76-86. [In Russian.]

Karatajūte-Talimaa, V. N. \& Brazauskas, A. 1994. Distribution of vertebrates in the Silurian of Lithuania. Geologija 17, 106-14.

Karatajūtė-Talimaa, V. \& Märss, T. 2004. Subclass Thelodonti - reference chapter. In Novitskaya, L. I. \& Afanassieva, O. B. (eds.) [Agnathans and Early Fishes, Russian Academy of Sciences] GEOS, 12-68. [in Russian.]

Karatajūtè-Talimaa, V. N. \& Predtechenskyj, N. 1995. The ditribution of the vertebrates in the Late Ordovician and Early Silurian palaeobasins of the Siberian Platform. In Arsenault, M., Lelièvre, H. \& Janvier, P. (eds) Etudes sur les Vertébrés inférieurs (VIIe Symposium International, Miguasha, Québec, 1991). Bulletin du Muséum National d'Histoire Naturelle, 4e serie 17C(1-4), 39-55.

Karatajūtè-Talimaa, V. N. \& Ratanov, L. S. 2002. Distribution of vertebrates in Upper Ordovician-Lower Devonian of Tuva (Russia). In J. Satkūnas, J. \& Lazauskienè (eds) Basin Stratigraphy modern methods and problems, The Fifth Baltic Stratigraphic Conference, Abstracts, 75-76.

Karatajūtè-Talimaa, V. N. \& Smith, M. M. 2003. Early acanthodians from the Lower Silurian of Asia. Transactions of the Royal Society of Edinburgh: Earth Sciences 93(for 2002), 277-99.

Karatajute-Talimaa, V. N. \& Žigaite, Ž. 2005. Tesserae of a new early vertebrate genus from Lower Silurian (Llandovery) of South Siberia - the exoskeleton of Galeaspida? In Hairapetian, V. \& Ginter, M. (eds) IGCP 491 meeting, Yerevan, Ichthyolith Issues Special Publication 8, 18

Karatajūtè-Talimaa, V. N. \& Žigaitè, Ž. 2006. New early vertebrate genus from Lower Silurian of south Siberia - the case of tesserated Galeaspida. In 2nd International Palaeontological Congress, Beijing, Ancient Life and Modern Approaches, Abstracts, 145-46.

Kiaer, J. 1932. New Coelolepids from the Upper Silurian on Oesel (Estonia). In Heintz, A. (ed.) Publications of the Geological Institution of Tartu University 10(1), 1-8.

Märss, T. 2003. Paralogania from the Paadla Stage, Ludlow, of Estonia. Proceedings of the Estonian Academy of Sciences, Geology 52(2), 98-112.

Märss, T. 1986. Squamation of the thelodont agnathan Phlebolepis Journal of Vertebrate Paleontology 6(1), 1-11.

Märss, T., Wilson, M. V. H. \& Thorsteinsson, R. 2002. New thelodont (Agnatha) and possible chondrichthyan (Gnatosthomata) taxa established in the Silurian and Lower Devonian of Arctic Canada Proceedings of Estonian Academy of Sciences: Geology 51(2), 88120.

Märss, T., Wilson, M. V. H. \& Thorsteinsson, R. 2006. Silurian and Lower Devonian thelodonts and putative chondrichthyans from the Canadian Arctic Archipelago (Cornwallis, Baillie-Hamilton, Devon, and Prince of Wales Islands). Special Papers in Palaeontology 75, 1-140.

Märss T., Turner, S. \& Karatajūtè-Talimaa, V. N. 2007. Agnatha II -Thelodonti. Handbook of Palaeoichthyology 1B, 143.

Märss, T. \& Karatajute-Talimaa, V. 2002. Ordovician and Lower Silurian thelodonts of Severnaya Zemlya Archipelago. Geodiversitas 24(2), 381-404

Märss, T. \& Miller, C. G. 2004. Thelodonts and distribution of associated conodonts from the Llandovery-lowermost Lochkovian of the Welsh Borderland. Palaeontology 47(5), 1211-66.

Märss T. \& Ritchie A. 1998. Articulated thelodonts (Agnatha) of Scotland. Transactions of the Royal Society of Edinburgh: Earth Sciences 88(for 1997), 143-95.

Minjin, Ch. 2001. Notes to Accompany the Correlation of the Ordovician and Silurian Rocks of Mongolia. In Webby, B. D., Talent, J.
A., Minjin, Ch., Tumenbayar, B. \& Sersmaa, G. (eds) Mongolian Field Guide, Ordovician and Silurian stratigraphy of Mongolia Tempus-Tacis Project 20091-98 Publication, 96-107. Ulaanbaatar.

Moskalenko, T. A. 1968. Llandoverian Agnathan Fossils in Siberia. In Obruchev, D. V. (ed.) Studies on Phylogeny and Systematicsof fossil fishes and agnathans, 29-32. Moscow: Nauka.

Rozman, K. S. 1986. The early Silurian brachiopods of the genus Tuvaella from Mongolia. Paleontologicheskii Zhurnal 1986(2), 29-38.

Sansom, R. S. 2009. Endemicity and palaeobiogeography of the Osteostraci and Galeaspida: a test of scenarios of gnathostome evolution. Palaeontology 52(6), 1257-73.

Stetson, H. C. 1931. Studies on the morphology of the Heterostraci. Journal of Geology 39, 141-54.

Tesakov, Y. I., Predtetchensky N. N., Khromych, V. G., Berger, A. Ya. \& Kovalevskaya, E.O. 2003. Stratigraphy and Palaeogeography of the Silurian of East Siberia. In Landing, E. \& Johnson, M. E. (eds) Silurian Lands and Seas: Paleogeography Outside of Laurentia. New York StateMuseum Bulletin 493, 345-400.

Traquair, R. H. 1898. Report on fossil fishes. Summary of progress of the Geological Survey of the United Kingdom for 1897, 72-76. London: HMSO

Turner, S. 1991. Monophyly and Interrelationships of the Thelodonti. In Chang, Mee-Mann, Liu, Yu-Hai \& Zang, Guo-Rui (eds) Early Vertebrates and Related Problems of Evolutionary Biology, 87119. Beijing: Science Press.

Turner, S. 1999. Early Silurian to Early Devonian thelodont assemblages and their possible ecological significance. In Boucot, A. J. \& Lawson, J. (eds) Palaeocommunities - a case study from the Silurian and Lower Devonian. IGCP Project "Ecostratigraphy", Final Report, 42-78. Cambridge, UK: Cambridge university Press.

Turner, S. 2000. New Llandovery to early Pridoli microvertebrates including Early Silurianzone fossil, Loganellia avonia nov. sp., from Britain. In Blieck, A. \& Turner, S. (eds) IGCP: 328, Final Report. Courier Forschungsinstitut Senckenberg 223, 91-127.

Turner, S. \& Nowlan, G. S. 1995. Early Silurian microvertebrates of eastern Canada. Bulletin du Muséum National d'Histoire Naturelle 4ème series, section C 17, 513-29.

Turner, S. \& Peel, J. S. 1986. Silurian thelodont scales from north Greenland. In Peel, J. S. (ed.) North Greenland Lower Palaeozoic Palaeontology and Stratigraphy: shorter contributions. Rapport Gronlands Geologiske Undersogelse 132, 79-88.

Vladimirskaya E. V., Eltysheva R. S. \& Krivobodrova A. V. 1986. [The questions of paleobiogeography and stratigraphy of Silurian of Tuva according to the new data on brachiopods from Tchergak Series]. Transactions of Leningrad Institute of Mines 107, 26-35. [In Russian.]

Wang, Ch., Li, N., Sun, Y. \& Zong, P. 2011. Distribution of Tuvaella Fauna and Its Tectonic Significance. Journal of Earth Sciences 22(1), 11-19.

Žigaite, Ż. 2004. A new thelodont from Lower Silurian of Tuva and north-west Mongolia. Acta Universitatis Latviensis 679, 158-65.

Žigaite Ž., Karatajūtė-Talimaa, V. N. \& Blieck, A. 2011. Vertebrate microremains from the Lower Silurian of Siberia and Central Asia: palaeobiodiversity and palaeobiogeography. Journal of Micropalaeontology 30, 97-106.

Žigaite, Ž. \& Blieck, A. 2006. Palaeobiogeographical significance of Early Silurian thelodonts from central Asia and S Siberia. GFF 128, 203-06.

Žigaite, Ž. \& Blieck, A. 2013. Palaeobiogeography of Early Palaeozoic vertebrates. In Servais, Th. \& Harper, D. A. T. (eds) Lower Palaeozoic Palaeobiogeography and Palaeogeography. Geological Society, London, Special Publications. In press.

Žigaite, Ž. \& Goujet, D. 2012. New observations on the squamation patterns of articulated exoskeletons of Loganellia scotica (Vertebrata: Thelodonti) from the Lower Silurian of Scotland. Geodiversitas 34(2), 253-70.

Žigaite, Ž. \& Karatajūtè-Talimaa, V. N. 2008. New genus of chondrichthyans from the Silurian-Devonian boundary deposits of Tuva. In Ginter, M. (ed.) Acta Geologica Polonica 58(2), 127-31. 